\title{
IMPACT OF OWNERSHIP STRUCTURE ON RISK-TAKING BEHAVIOR OF SOUTH ASIAN BANKS
}

\author{
Ahmed Imran Hunjra ${ }^{*}$, Tahar Tayachi ${ }^{* *}$, Rashid Mehmood ${ }^{* * *}$ \\ * Corresponding author, University Institute of Management Sciences, PMAS-Arid Agriculture University Rawalpindi, Pakistan \\ Contact details: ahmedhunjra@gmail.com \\ ** Chair of Finance Department, Effat University, Saudi Arabia \\ *** University Institute of Management Sciences, PMAS-Arid Agriculture University Rawalpindi, Pakistan
}

OPEN ACCESS
How to cite this paper: Hunjra, A. I.,
Tayachi, T., \& Mehmood, R. (2020). Impact
of ownership structure on risk-taking
behavior of South Asian banks. Corporate
Ownership \& Control, 17(3), 108-120.
http://doi.org/10.22495/cocvl7i3art8
Copyright $\odot 2020$ The Authors
This work is licensed under a Creative
Commons Attribution 4.0 International
License (CC BY 4.0).
https://creativecommons.org/licenses/by/
$4.0 /$
ISSN Online: $1810-3057$
ISSN Print: $1727-9232$
Received: 17.02 .2020
Accepted: 30.03 .2020
JEL Classification: G32, G38
DOI: 10.22495/cocv17i3art8

How to cite this paper: Hunjra, A. I., Tayachi, T., \& Mehmood, R. (2020). Impact 作 Ownership \& Control, 17(3), 108-120.

Copyright $(2020$ The Authors License (CC BY 4.0).

https://creativecommons.org/licenses/by/

DOI: $10.22495 /$ cocvl7i3art8

\begin{abstract}
The implementation of an effective risk management policy is necessary for the survival and success of banks. Ownership structure changes the risk-taking behavior of banks. Therefore, we analyze the impact of the ownership structure on risk-taking behavior of banks in emerging markets (i.e., Pakistan, India, and Bangladesh). We take public, private and foreign ownership of banks in this study. We collect the data from 64 banks of selected countries from 2011 to 2018. We measure risk-taking as capital adequacy, leverage coverage ratio, non-performing loan ratio, and return volatility. We use two-step system dynamic panel estimation for analyzing the results. We find that public and private banks have significant relationship with the risk-taking of banks. Furthermore, public and private banks show more risk-taking behavior as compared to foreign banks in all selected countries.
\end{abstract}

Keywords: Ownership Structure, Risk-Taking, Return Volatility, Two-Step Dynamic Panel, Hetero and Auto Generalized Least Square

Authors' individual contribution: Conceptualization - A.I.H. and R.M.; Methodology - A.I.H., T.T., and R.M.; Formal Analysis - A.I.H. and R.M.; Writing - Original Draft - T.T. and R.M.; Writing - Review \& Editing - A.I.H. and T.T.; Supervision - A.I.H.

Declaration of conflicting interests: The Authors declare that there is no conflict of interest.

\section{INTRODUCTION}

We select emerging countries for our study because these countries present a unique economy. Emerging markets usually represent financial markets of fast growing economies having social, political, and economic improvement over the recent decades (Boubaker \& Nguyen, 2014). The banking sector is the key part of the economy of South Asian countries and a stable and profitable system of this sector is the requirement for a strong economy (Nisar, Peng, Wang, \& Ashraf, 2018). According to the report of the World Bank 2016, South Asia earns the fastest growth in its economy. Reforms in ownership structure lead to changes in risk-taking behavior of banks over the last few years (Barry, Lepetit, \& Tarazi, 2011). Banking ownership is concerned with the transfer of funds from a customer to the credit creation and vice versa. Banks cover the investments through loans and they provide an interest-based business to the financial market. These financial markets are controlled by the central banking system which acts as an intermediary (Hammami \& Boubaker, 2015). These banking investments are highly risky and the leverage is mostly in the shape of liquid assets. In private banks, management and shareholders are keen because of having their assets to benefit from investment and risk related to this. The information of private banks is easy to obtain for loan providing facilities. Further, it is easy to forecast financial information to avoid risk. In addition, private banks have more problems as compared to public banks because they have no shelter under the Federal Reserve agencies or central 
banks (García-Marco \& Robles-Fernández, 2008). Banks management thinks that public or private ownership is not concerned with the investment or profitability of banks. Instead, the ownership structure of banks is concerned with methods of providing loans, and the nature of risk. However, state-owned banks have also a weak financial system (La Porta, Lopez-de-Silanes, \& Shleifer, 2002). In addition, ownership structure also focuses on decreasing insolvency risk. However, state-owned banks have lower quality of the loan and increased insolvency risk as compared to mutual and private banks (Iannotta, Nocera, \& Sironi, 2007).

The bank's traits and regulatory institutions are different in developing countries as opposed to developed countries (Haque \& Shahid, 2016). The family ownership banks are less risky whereas the conventional banking system is more stable due to the public interest (Srairi, 2013). The behavior of risk-taking of foreign, private, and public banks is an important element to analyze. Riskier investments could be controlled by the interest rate mechanisms designed by the managers of the financial system. Profit-maximizing strategies are attached to a higher level of risk. The risk value provides the features of credit risk, interest risk, liquidity risk which affect the banking sector in South Asia and they face losses. Banks face losses because of credit risk attached to the related investments. There was a collapse in the private banking sector in the last decade which was due to capital investment in the business of the real estate. The banking sector provides a large amount of house building loans, home finance, or loans for business purposes to real estate investors. People get loans against their liquid or current assets and if they do not pay back the loan, ultimately banks have to bear the burden. Hence, banks are unable to recover the loan amount along with interest which leads them to bear losses and ultimately they collapse. In contrast, public banks bear more safety in terms of the loan amount as well as interest amount. Ben-Nasr, Boubaker, and Rouatbi (2015) document that the structure of the firms shows a significant relationship with risk related patterns. Publicly owned banks enjoy a certain level as compared to foreign and private banks. Risk-taking activities and structure of ownership in public banks are different from foreign banks.

Rules and regulations of banks in a country raise their charter values. A bank's risk-related behavior is related to various factors including structure of ownership, macroeconomic factors, and charter value. Allen and Paligorova (2011) explain that the structure of a firm is concerned with riskrelated activities; therefore, they have positive relationship. The basic ownership structure of banks is related to the values and risk-related behavior which is concerned about getting a loan and providing it to the investors. All forms of banks work efficiently when there is security for them. Investors are more reluctant while investing in private banks, but they believe their investment to be saved when they invest in public banks. With the growth of the economy in developing countries, the banking sector is also growing which requires more emphasis on the risk-taking patterns.
Governance and risk-taking behavior of banks have greater importance because bank managers are keen to identify the key governance qualities, which need to be stronger. These features help to realize better transparency and develop investors' confidence and minimize asymmetric information (Miller \& Skinner, 2015; El-Bannany, 2018). In addition, effectively governed banks are expected to provide rigorous reviews of their investments and keep healthy risk profiles (Faleye \& Krishnan, 2017). These evidences show that there exists relationship between governance and risk-taking of the banking sector.

Banks in most of the developing countries have ownerships of foreign, private and state investors. During the last decade, most studies on the banking sector regarding the structure of ownership and risk-related activities have focused on developed countries (Srairi, 2013; Zhu \& Yang, 2016; Jamil, Said, \& Nor, 2015). Zhu and Yang (2016) explain that private and foreign banks have increased monitoring ability that significantly influences risk-related activities of banks. The previous three decades are characterized by the continual crisis in the financial sector of South Asian countries which leads to the evolution of different risk trends, thus making it important to study the South Asian markets with the perspective of ownership impact on risk-taking patterns. One of the most important issues in the South Asian banking industry is the understanding of whether risk-related activities among publicly and foreign-owned banks differ significantly or not.

Foreign investors conduct monitoring in publicly owned banks. However, private investors help improve governance system in publicly owned banks. Monitoring also helps to reduce bank risks. Emerging countries have a weak governance system (Hunjra, Perveen, Li, Chani, \& Mehmood, 2020). Therefore, their economy is regionally not a solid equity provider. The weak market, savings, economy, and weak equity are unable to attract foreign bankers to make investments. People trust public banks more than non-listed banks. Listed banks have a positive impact in the case of risk-taking while the non-listed have a negative impact due to their risky investments and short life. The legal environment affects the relation of ownership structure and credit risk-taking. Foreign banks have shown lesser interest in Bangladesh banks due to the small market. The capital risk in Pakistan and Bangladesh is more often than in India, while the non-performing loan in developing nations is also a major problem. Further, in Pakistan, India, and Bangladesh, banks play a significant part in their countries and are key lenders to both government and private sectors (Perera, Skully, \& Wickramanayake, 2006). The banks are the backbone of these emerging economies and a profitable, diverse and stable system of banks is obligatory for prosperous and growing economies (Nisar et al., 2018).

Financial institutions and banks confront risk in daily business activities which may result in the default of banks. Therefore, the implementation of an effective risk management policy is necessary for the success and survival of banks. Because a change in ownership structure leads to a change in the 
risk-taking of banks (Barry et al., 2011), the objective of our study is to check the impact of ownership structure on risk-taking behavior in Pakistan, India, and Bangladesh. Furthermore, we investigate that either the risk-taking is higher in publicly owned, foreign-owned and privately owned banks. Our study may provide the guide to policymakers in designing financial policies given the structure of the firms and risk-related behavior. In addition, banks can make economically sound decisions that are not only going to reflect the influence of ownership structure on risk but also help in constructing sound financial policies.

The remainder of the paper is structured as follows: we provide brief literature for hypotheses development in Section 2, followed by data and methodology presented in Section 3. Section 4 explains the empirical results, while Section 5 concludes the paper with insights for further studies.

\section{REVIEW OF LITERATURE AND HYPOTHESES DEVELOPMENT}

There have been theoretical and empirical evidence of literature which attempts to analyze the banks' risk-taking behavior. Review of literature suggests that public, private and foreign ownerships play a vital role in influencing bank risk-taking. Considering the agency theory of Jensen and Meckling (1976), there is a conflict between owners and managers. Further, the theory explains that managers behave in a risk-averse way in order to protect their personal benefits and their existing positions. There has been some latest and older literature concerning the analysis of bank risk either in emerging countries or developed countries. This section covers the literature about the impact of ownership structure on risk-taking behavior of banks across developed and emerging economies. Capital adequacy ratio represents the operational risk of banks. The ownership structure is the key component that affects operational risk.

La Porta et al. (2002) demonstrate that state ownership reduces operational risk due to the financial guarantee of state-owned banks. Allen and Paligorova (2011) said that risk and structure of a firm show a positive relation of a large shareholder. Liu, Molyneux, and Nguyen (2012) conclude that a decline in the charter values increases the benefit of the risk-taking of banks. Barry et al. (2011) investigate risk-related activities in public and private banks of Europe. Private banks are riskier because families or individuals hold the large shareholding of the banks. Findings show that a higher stake of equity holders makes the strategies to manage the risk sometimes called the riskiest plan. Publicly owned and privately owned banks have different risks and profits due to different ownership structures. Iannotta, Nocera, and Sironi (2013) find the impact of government ownership on banks' risk. Government ownership is mostly connected with the high level of risk-taking, as the government bears the cost of excessive risk-taking. They find a positive influence of government ownership and operational risk. They further explain that state-owned banks represent a lower level of efficiency, high long term performance, a higher level of risk, and less concern about lending. Jamil et al. (2015) figure out the connection between capital adequacy and private ownership are important factors in risk-taking. Zhu and Yang (2016) find that state-owned banks show high risk, while foreign investments significantly influence risk-taking activities. It helps to decrease the bank risk by increasingly involved in the monitoring of investments. Foreign and private banks show a lower risk level as compared to public banks. Duqi and AlTamimi (2018) conduct research and find that foreign and privately owned banks have significant relationship with capital adequacy. Choi and Hasan (2005) explain that foreign banks negatively affect risk. We take the capital adequacy ratio as a measure of risk because it determines the level of adequate capital. Zeitun and Tian (2007) describe that foreign and government ownership decreases bank default risk. Sustaining high capital adequacy helps to reduce the economic cost of banking crises (Fullenkamp \& Rochon, 2016). To maintain the solvency of banks, it is important to maintain adequate capital. Therefore, we develop the following hypothesis regarding the impact of ownership structure on capital adequacy ratio:

H1: Ownership structure has a significant impact on capital adequacy ratio.

Brandao-Marques, Correa, and Sapriza (2012) examine bank risks through increasing charter value of banks and reducing market discipline. The government charter value of banks protects the banks in the future through a certain increase in the value of financial cost, which is affected by the creditor demand on low rates, to reduce the risk-taking in the banks. Risk-taking exceeds when banks fail in risk management and the government of the country charges high rescue cost which enhances the risks. Organizational structure is important and affected by the risk-taking of the bank when banks face losses that create conflict between managers and owners of the banks. If the banks are influenced by the creditor or assisted with government support, then it reduces the risk in the banking sectors. Zhang, Jiang, Qu, and Wang (2013) address banks risk-taking behaviors through foreign ownership entry.

Foreign investment increases bank efficiency and the competitive advantages in banks. Banks provide the loan to the small, medium-size companies which are associated with the foreign banks. Banks are also keen to manage liquidity risk for stability in business matters because liquidity is the ability to finance an increase in assets and pay liabilities when they become due with no unexpected loss. Ownership of banks plays a significant role in managing liquidity risk. Andries and Billon (2010) describe that state-owned banks show low liquidity risk because depositors believe that their deposits are well protected in state-owned banks. Therefore, state-owned banks have stability in their deposits. Trinh, Duyen, and Thao (2015) explain that foreign ownership shows a significant impact on liquidity and credit risk in banks of Vietnam. Duqi and Al-Tamimi (2018) signify that private banks have a lower level of liquidity risk as opposed to foreign and government banks. Samet, Boubakri, and 
Boubaker (2018) conclude that public banks are less risky than private banks. Based on the literature review, we propose the following hypothesis:

H2: Ownership structure has a significant impact on the leverage coverage ratio.

In developed countries, the risk-taking behavior plays a vital role for legal protection to corporate ownership. It is examined that the ownership concentration is very important for performance rather than to give importance to risk-taking. Dong, Meng, Firth, and Hou (2014) investigate the relationship between ownership structure and risk of banks in China and they classify commercial banks in three types based on controlling shareholders, i.e., government banks, state-owned enterprises and controlled banks and private banks. They find that government banks are riskier as opposed to other forms of banks in the study because of weak management practices and political involvement. The literature on ownership structure and risk presents two views. One view is concerned with social lending, moral hazard and agency cost. One view is based on moral hazard, social lending, and agency cost. Public ownership has a high risk because they have inefficient utilization of resources and poor managerial rewards and practices (Barry et al., 2011). Another view is concerned with the theory of soft budget constraints and market-related risk. The theories justify that publicly owned banks apply political solutions of the issues like non-performing loans and increase finance which results in decreasing risk. Li (1992) argues that the reason that the socialist economies are more prone than that of capitalist counterparts of soft budget constraints is that socialism entails public ownership of capital. Iannotta et al. (2007) conduct a study in Europe and find that state-owned banks have lower quality of loan and increased insolvency risk as compared to mutual and private banks.

Iannotta et al. (2013) investigate a study by taking a sample of European banks and find that government ownership has a negative impact on the default risk of banks. Srairi (2013) investigates a study in the Middle East and North Africa (MINA) countries and finds a significant and positive impact of publicly owned banks on credit risk which signifies that publicly owned banks have a large part of non-performing loans. They also conclude that state ownership and banking system performance have a negative relationship. Drakos, Kouretas, and Tsoumas (2016) describe that risk-related activities are different in foreign in domestic banks. When the interest rate is low, then foreign banks increase their risk-taking whereas the reaction of domestic banks maybe vice versa. Based on a review of literature on credit risk, we develop the following hypothesis:

H3: Ownership structure has a significant impact on non-performing loan.

Jamil et al. (2015) state that ownership structure is one of the major factors of risk-taking. They conclude the ownership structure has an impact on banks' risk-taking behavior. Ownership structure also concerns the volatility risk. This form of risk is a major area for banks because the basic aim of banks is to increase profitability and reduce uncertainty in income. Past studies suggest that ownership plays a significant role in affecting volatility risk. Djankov and Murrell (2002), Estrin, Hanousek, Kocenda, and Svejnar (2009), and Boubakri, Cosset, and Saffar (2013) justify in their studies that foreign ownership results in increased volatility risk.

H4: Ownership structure has a significant impact on return volatility.

\section{METHODOLOGY}

The purpose of our research is to analyze the impact of ownership structure on a bank's risk-taking behavior. We collect data of a total of 64 banks of Pakistan, India, and Bangladesh from the financial statements for the period 2011 to 2018. We select those banks whose data is available during the sample time period. Further, these banks fall into categories of private, public, or foreign ownership.

Table 1. Number of banks WRT ownership structure

\begin{tabular}{|l|c|c|c|c|}
\hline Country & $\begin{array}{c}\text { Foreign } \\
\text { banks }\end{array}$ & $\begin{array}{c}\text { Public } \\
\text { banks }\end{array}$ & $\begin{array}{c}\text { Private } \\
\text { banks }\end{array}$ & Total \\
\hline Pakistan & 3 & 5 & 13 & 21 \\
\hline India & 5 & 12 & 6 & 23 \\
\hline Bangladesh & 4 & 4 & 12 & 20 \\
\hline Total & 12 & 21 & 31 & 64 \\
\hline
\end{tabular}

\subsection{Statistics}

We use five measures of risk-taking, i.e., non-performing loans, the standard deviation of ROA, the standard deviation of ROE, capital adequacy ratio and liquidity coverage ratio. We use control variables like revenue growth, diversification, ROA, firm size, firm age and cost to income ratio. We measure the ownership structure of banks as a dummy variable. We explain the measurement of variables in Table 2. 
Table 2. Variables and their proxies

\begin{tabular}{|c|c|c|c|}
\hline Variables & Proxies & Symbols & References \\
\hline Ownership structure & $\begin{array}{l}\text { The ownership structure of firm states which entity owns } \\
\text { most shares of the firm or fully owns. }\end{array}$ & $\begin{array}{l}\mathrm{FB}, \mathrm{PB} \\
\mathrm{PVB}\end{array}$ & $\begin{array}{l}\text { Yao, Haris, and Tariq } \\
(2018)\end{array}$ \\
\hline $\begin{array}{l}\text { Capital adequacy } \\
\text { ratio }\end{array}$ & $\frac{\text { Tier } 1 \text { Capital + Tier } 2 \text { Capital }}{\text { Risk-Weighted assets }}$ & CAR & $\begin{array}{l}\text { Rime (2001); Maji and De } \\
\text { (2015) }\end{array}$ \\
\hline $\begin{array}{l}\text { Leverage coverage } \\
\text { ratio }\end{array}$ & Earnings before interest and tax to interest expense. & LCR & Pinto and Rastogi (2019) \\
\hline Non-performing loan & $\begin{array}{l}\text { NPL is the sum of the borrowed amount upon which the } \\
\text { debtor fails to pay scheduled payments for at least } 90 \text { days. } \\
\text { We use the following formula to calculate NPL: } \\
\qquad \frac{\text { Non - performing loan }}{\text { Total loan }}\end{array}$ & NPL & $\begin{array}{l}\text { Lotto and Mwemezi (2015); } \\
\text { Lotto (2018) }\end{array}$ \\
\hline $\begin{array}{l}\text { Standard deviation of } \\
\text { ROE }\end{array}$ & Return volatility of the bank. & $\delta(\mathrm{ROE})$ & Aharon and Yagil (2019) \\
\hline $\begin{array}{l}\text { Standard deviation of } \\
\text { ROA }\end{array}$ & Return volatility of the bank. & $\delta(\mathrm{ROA})$ & Aharon and Yagil (2019) \\
\hline Diversification & $1-\left|\frac{\text { Net interest income }- \text { Other income }}{\text { Total income }}\right|$ & $\mathrm{D}$ & Nisar et al. (2018) \\
\hline Revenue growth & $\frac{\text { Current revenue }- \text { Previous revenue }}{\text { Previous revenue }}$ & RG & $\begin{array}{l}\text { Mehmood, Hunjra, and } \\
\text { Chani (2019) }\end{array}$ \\
\hline Profitability (ROA) & Net income to the total assets of the firm. & ROA & $\begin{array}{l}\text { Chiorazzo, Milani, and } \\
\text { Salvini (2008) }\end{array}$ \\
\hline Size & Natural log of total assets. & S & $\begin{array}{c}\text { Boubaker, Nguyen, and } \\
\text { Rouatbi (2016); Yao et al. } \\
\text { (2018); Hunjra, Mehmood, } \\
\text { \& Tayachi (2020) }\end{array}$ \\
\hline Cost to income ratio & Operating cost to operating income of the firm. & $\mathrm{CI}$ & Lotto $(2018)$ \\
\hline
\end{tabular}

Notes: FB = Foreign banks; $P B=$ Public banks; $P V B=$ Private banks; ROA = Return on assets.

We use the following statistical model to analyze the data:

$$
\begin{gathered}
(R)_{i, t}=\alpha+\beta_{1}(O S)_{i, t}+\beta_{2}(D)_{i, t}+\beta_{3}(R G)+ \\
\beta_{4}(R O A)+\beta_{5}(S)+\beta_{2}(C I)+\mu_{i, t}
\end{gathered}
$$

where $R=$ risk (capital adequacy ratio, leverage coverage ratio, non-performing loans, standard deviation of ROE, and standard deviation of ROA); $O S=$ ownership structure (foreign ownership, public ownership, and private ownership); $D=$ diversification; $\quad R G=$ revenue $\quad$ growth; $R O A=$ return on assets; $S=$ bank size; $C I=$ cost to income ratio; $\alpha=$ constant; $\beta_{1}$ to $\beta_{6}=$ coefficient; and $\mu=$ error term.

\section{ANALYSIS}

We use descriptive statistics in Table 3 to summarize the data by explaining the mean and standard deviation of each variable. In addition, the table explains correlation analysis which explains the relationship between explanatory variables and the problem of multicollinearity. Outputs reveal that CAR is very low. It is the percentage of banks' risk-weighted credit exposure, lower ratio indicates a higher risk which shows that firms in emerging markets face higher. The mean liquidity coverage ratio shows that on average solvency/liquidity risk of banks is higher as compared to Pakistan and Bangladesh, it is lowest for Pakistani banks.
NPL is a deputation for credit risk has a very low mean value which indicates the lower credit risk banks in emerging markets. Further, there are least chances of default and banks manage their debtors efficiently. The mean value of $\sigma \mathrm{ROA}$ shows that Pakistan has high return volatility as compared to the mean value of $\sigma$ ROE. Results indicate that nearly half of the banks are privately owned whereas almost one-third of the banks are publicly owned. However, the ratio of foreign banks operating in emerging markets is less than 20\%. The mean value of ROA shows that on average, banks bear losses with a very lower percentage. Firm size measured as a natural $\log$ of total assets shows the stability of banks in the investment of total assets. Due to the demand for volatile business activities in banks, they are paying more attention to income diversification because it shows a major part of total income. Revenue growth also shows an increasing trend due to diversified business activities. Results also indicate that banks are bearing high cost to income ratio. The standard deviation shows that all the variables have stable values except for the cost to income ratio which shows a large variation in the values of cost to income. Return on assets also shows increase in volatility in the values. The results of the correlation analysis represent there is no multicollinearity, which signifies that all the variables can be included in the final estimation. All variables show a weak association because the highest value of correlation does not exceed the prescribed limit. 
Table 3. Descriptive statistics and correlation analysis

\begin{tabular}{|c|c|c|c|c|c|c|c|c|c|c|c|c|c|c|c|}
\hline & Mean & S.D. & $C A R$ & $L C R$ & NPL & $\sigma R O E$ & $\sigma R O A$ & $F B$ & $P B$ & $P V B$ & $D$ & $R G$ & $R O A$ & $S$ & $C I$ \\
\hline CAR & 0.179 & 0.144 & 1.000 & & & & & & & & & & & & \\
\hline LCR & 0.286 & 0.329 & 0.079 & 1.000 & & & & & & & & & & & \\
\hline NPL & 0.079 & 0.104 & 0.280 & 0.179 & 1.000 & & & & & & & & & & \\
\hline$\sigma \mathrm{ROE}$ & 0.116 & 0.283 & -0.073 & -0.034 & 0.033 & 1.000 & & & & & & & & & \\
\hline$\sigma \mathrm{ROA}$ & 0.422 & 2.311 & 0.128 & 0.071 & 0.108 & 0.002 & 1.000 & & & & & & & & \\
\hline FB & 0.188 & 0.391 & 0.068 & -0.259 & -0.170 & -0.021 & -0.075 & 1.000 & & & & & & & \\
\hline $\mathrm{PB}$ & 0.328 & 0.470 & 0.033 & -0.266 & 0.068 & 0.014 & 0.128 & -0.336 & 1.000 & & & & & & \\
\hline PVB & 0.484 & 0.501 & -0.085 & 0.453 & 0.069 & 0.004 & -0.062 & -0.466 & -0.677 & 1.000 & & & & & \\
\hline D & 0.249 & 0.288 & 0.104 & 0.272 & 0.280 & -0.020 & 0.118 & 0.078 & -0.126 & 0.058 & 1.000 & & & & \\
\hline RG & 0.213 & 0.200 & 0.094 & 0.243 & -0.050 & -0.011 & -0.082 & 0.082 & -0.341 & 0.256 & 0.166 & 1.000 & & & \\
\hline ROA & -0.006 & 2.113 & -0.014 & 0.016 & 0.004 & -0.015 & -0.290 & 0.010 & -0.025 & 0.015 & 0.001 & -0.004 & 1.000 & & \\
\hline S & 17.138 & 4.775 & -0.284 & -0.198 & -0.245 & 0.008 & -0.237 & -0.060 & 0.001 & 0.046 & -0.278 & -0.110 & 0.025 & 1.000 & \\
\hline $\mathrm{CI}$ & 4.618 & 24.124 & -0.038 & 0.073 & 0.049 & 0.089 & 0.017 & 0.050 & -0.076 & 0.032 & 0.079 & -0.085 & 0.012 & -0.026 & 1.000 \\
\hline
\end{tabular}

Table 4. Test for multicollinearity

\begin{tabular}{|l|c|c|}
\hline \multicolumn{1}{|c|}{ Variable } & VIF & 1/VIF \\
\hline FB & 1.46 & 0.685 \\
\hline PB & 1.99 & 0.503 \\
\hline PVB & 1.86 & 0.537 \\
\hline RG & 1.18 & 0.846 \\
\hline D & 1.12 & 0.891 \\
\hline S & 1.10 & 0.911 \\
\hline CI & 1.03 & 0.972 \\
\hline M & 1.00 & 0.999 \\
\hline \multicolumn{2}{|c|}{ Notes: VIF $=$ variance inflation factor. }
\end{tabular}

We explain the variance inflation factor (VIF) to verify the problem of multicollinearity in our analysis in Table 4. Outcomes indicate that VIF values are not more than 3 , therefore we justify that the multicollinearity problem does not exist in our study.

In Table 5, we determine the impact of ownership structure on risk-taking behavior of banks in selected countries. For the analysis of data, we apply the generalized method of moments (GMM) to handle the problem of endogeneity. For this reason, we use two-step dynamic panel regression which is suitable for a short period and long cross-sectional data. Arellano and Bond (1991) and Arellano and Bover (1995) developed this technique. The technique helps to deal with autoregressive properties of the dependent variable and to handle the issue of endogeneity prevailing in dependent variables along with unabsorbed firm specified characteristics (González, 2013). In addition, for reliability of instrument homogeneity test, we systematically verify that the number of instruments is less than the number of groups. We apply Sargan test for the validity of instruments. Insignificant values indicate that instruments are valid. We run Arellano-Bond test to check autocorrelation. AR2 reveals insignificant outcomes that lead us to accept the null hypothesis that there is no autocorrelation. Results indicate that public and private banks have a significant impact on bank risk. Moreover, results reveal that foreign ownership does not have a significant impact on bank risk due to less dominance of foreign ownership of banks in South Asian countries. However, public and private banks have a positive impact on capital adequacy ratio. This indicates that public banks are more proficient in following regulations and they keep on meeting the adequacy ratio of capital while private banks aim at maximizing their profit that helps to increase capital adequacy ratio. In addition, government protection is more connected with risk-taking (Demirgüç-Kunt \& Detragiache, 2002). Findings further indicate that publicly owned banks have significant positive while private banks have a significant and negative impact on non-performing loans. The results are similar to the outcomes of Nichols, Wahlen, and Wieland (2009) which state that private banks have less loan losses while public banks have more loan losses. This further signifies that privately owned banks have more control over the recovery of loans. Creditors are more concerned about paying back loan to private banks.

In addition, both private and public banks have a significant and positive impact on leverage coverage ratio and volatility of return on equity. Findings of leverage coverage ratio suggest that ownership pattern increases the capacity of banks to pay fixed interest charges to their creditors. Moreover, all forms of bank ownership of our study have a significant impact on the volatility of return on assets. In addition, publicly owned banks have a positive influence on the volatility of return on assets which signifies that when public ownership has more stakes in banks, they tend to increase the risk of banks (Ashfaq, Younas, \& Mehmood, 2014). Findings justify that publicly owned banks have more assets risk and they tend to bear higher default risk (Iannotta et al., 2007). Further, a significant and negative impact of privately owned banks on the volatility of return on assets justifies that private banks are more conservative and less risky when utilizing their assets.

Findings reveal that income diversification has a significant and positive impact on liquidity risk which signifies that when banks involve in diversified income sources, they face more risk-taking activities. The findings are similar to the results of Williams (2016). However, it has an insignificant impact on capital adequacy ratio and non-performing loans which justifies that when banks opt for a diverse source of income, they are not concerned about their regular capital generation and non-performing loan.

In addition, income diversification has a significant and positive impact on the volatility of return on assets. Stiroh and Rumble (2006) also report a positive impact of diversified income on bank risk. Lepetit, Nys, Rous, and Tarazi (2008) describe that an increase in bank risk is not due to the trading activities of banks; rather it is due to the non-trading activities. Further, diversification shows a significant and positive impact on the volatility of return on equity only when we consider privately owned banks. 
Table 5. Two-step system dynamic panel regression analysis (overall)

\begin{tabular}{|c|c|c|c|c|c|c|c|c|c|c|c|c|c|c|c|}
\hline & CAR & CAR & CAR & $L C R$ & $L C R$ & $L C R$ & NPL & NPL & NPL & $\delta R O E$ & $\delta R O E$ & $\delta R O E$ & $\delta R O A$ & $\delta R O A$ & $\delta R O A$ \\
\hline L1. & $\begin{array}{c}1.167 * \cdots * * * \\
(4.790)\end{array}$ & $\begin{array}{c}1.161^{\text {****** }} \\
(7.370)\end{array}$ & $\begin{array}{c}1.040^{* * * * *} \\
(4.910)\end{array}$ & $\begin{array}{c}-0.206 \\
(-0.900) \\
\end{array}$ & $\begin{array}{c}-0.685^{* * * * *} \\
(-2.820) \\
\end{array}$ & $\begin{array}{c}-0.682^{* * * * *} \\
(-3.220)\end{array}$ & $\begin{array}{c}0.865^{\ldots * * *} \\
(7.760) \\
\end{array}$ & $\begin{array}{l}0.969 * \cdots * * \\
(16.920)\end{array}$ & $\begin{array}{l}0.906^{* * * * *} \\
(15.330)\end{array}$ & $\begin{array}{c}0.349 * * * \\
(6.650)\end{array}$ & $\begin{array}{c}0.409 * \cdots * \\
(6.570)\end{array}$ & $\begin{array}{c}0.366^{* \cdots * * *} \\
(5.960)\end{array}$ & $\begin{array}{c}0.091 \\
(0.230) \\
\end{array}$ & $\begin{array}{c}0.429 * \cdots * \\
(4.020)\end{array}$ & $\begin{array}{l}0.804 * * * * \\
(11.390)\end{array}$ \\
\hline L2. & $\begin{array}{c}0.112 \\
(0.750) \\
\end{array}$ & $\begin{array}{c}0.031 \\
(0.270) \\
\end{array}$ & $\begin{array}{c}0.024 \\
(0.220) \\
\end{array}$ & $\begin{array}{c}-0.191 \\
(-0.870)\end{array}$ & $\begin{array}{c}-0.663^{* \ldots * k} \\
(-2.780)\end{array}$ & $\begin{array}{c}-0.656^{* * * *} \\
(-3.160)\end{array}$ & $\begin{array}{c}-0.010 \\
(-0.310)\end{array}$ & $\begin{array}{c}-0.012 \\
(-0.360)\end{array}$ & $\begin{array}{c}-0.016 \\
(-0.480)\end{array}$ & $\begin{array}{c}-0.166^{* * * *} \\
(3.130)\end{array}$ & $\begin{array}{c}-0.129^{* \ldots * k} \\
(-3.610)\end{array}$ & $\begin{array}{c}-0.198^{* * * * *} \\
(-3.860)\end{array}$ & $\begin{array}{c}-0.151 \\
(-1.400) \\
\end{array}$ & $\begin{array}{c}-0.459^{* * * *} \\
(-7.370)\end{array}$ & $\begin{array}{c}-0.536^{* \ldots k k} \\
(-8.420)\end{array}$ \\
\hline FB & $\begin{array}{c}-0.153 \\
(-0.770) \\
\end{array}$ & --- & --- & $\begin{array}{c}-0.371 \\
(-0.320) \\
\end{array}$ & --- & --- & $\begin{array}{c}-0.076 \\
(-0.750) \\
\end{array}$ & --- & --- & $\begin{array}{c}-0.287 \\
(-0.610) \\
\end{array}$ & --- & --- & $\begin{array}{c}-70.441^{* * *} \\
(-2.210)\end{array}$ & --- & --- \\
\hline PB & --- & $\begin{array}{l}0.058^{*} \\
(2.350)\end{array}$ & --- & --- & $\begin{array}{l}-0.695 \% * * \\
(-3.500)\end{array}$ & --- & --- & $\begin{array}{l}0.098^{\ldots * *} \\
(2.490)\end{array}$ & --- & --- & $\begin{array}{l}0.483 \text { *** } \\
(2.030)\end{array}$ & --- & --- & $\begin{array}{c}22.769 * * \cdots * \\
(3.840)\end{array}$ & --- \\
\hline PVB & --- & & $\begin{array}{c}0.105^{* * * * *} \\
(4.020)\end{array}$ & --- & & $\begin{array}{c}0.612^{* * * * *} \\
(3.530)\end{array}$ & & & $\begin{array}{l}0.061^{*} \\
(2.370)\end{array}$ & --- & --- & $\begin{array}{l}0.003^{*} \\
(1.820)\end{array}$ & --- & --- & 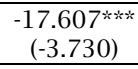 \\
\hline D & $\begin{array}{c}-0.051 \\
(-0.880)\end{array}$ & $\begin{array}{c}-0.035 \\
(-0.810)\end{array}$ & $\begin{array}{c}-0.050 \\
(-1.070)\end{array}$ & $\begin{array}{c}0.196^{* * * * *} \\
(3.410)\end{array}$ & $\begin{array}{l}0.154 \text { *** } \\
(2.490)\end{array}$ & $\begin{array}{l}0.171^{* * *} \\
(2.540)\end{array}$ & $\begin{array}{c}0.098 \\
(1.370)\end{array}$ & $\begin{array}{c}0.061 \\
(0.770) \\
\end{array}$ & $\begin{array}{c}0.059 \\
(0.730) \\
\end{array}$ & $\begin{array}{c}0.855 \\
(1.620) \\
\end{array}$ & $\begin{array}{c}0.698 \\
(1.610) \\
\end{array}$ & $\begin{array}{l}0.729 * \\
(1.880)\end{array}$ & $\begin{array}{c}1.914 \\
(0.600)\end{array}$ & $\begin{array}{l}1.179 * * \\
(2.280)\end{array}$ & $\begin{array}{l}1.399^{* * *} \\
(2.500) \\
\end{array}$ \\
\hline RG & $\begin{array}{c}-0.010 \\
(-0.270)\end{array}$ & $\begin{array}{c}-0.002 \\
(-0.050)\end{array}$ & $\begin{array}{c}-0.035 \\
(-1.120)\end{array}$ & $\begin{array}{c}-0.018 \\
(-0.260)\end{array}$ & $\begin{array}{c}-0.097 \\
(-1.240)\end{array}$ & $\begin{array}{c}-0.080 \\
(-0.990)\end{array}$ & $\begin{array}{c}-0.066 \\
(-1.400)\end{array}$ & $\begin{array}{l}-0.078^{*} \\
(-1.760)\end{array}$ & $\begin{array}{l}-0.082^{*} \\
(-1.730)\end{array}$ & $\begin{array}{c}0.071 \\
(0.490)\end{array}$ & $\begin{array}{c}0.096 \\
(0.700)\end{array}$ & $\begin{array}{c}0.087 \\
(0.600)\end{array}$ & $\begin{array}{c}0.263 \\
(0.580)\end{array}$ & $\begin{array}{c}0.147 \\
(1.230)\end{array}$ & $\begin{array}{c}0.203 \\
(1.480)\end{array}$ \\
\hline ROA & $\begin{array}{c}-0.002 \ldots+\cdots \\
(-4.270)\end{array}$ & $\begin{array}{c}-0.002 \\
(-6.580)\end{array}$ & $\begin{array}{c}-0.002 \\
(-3.400)\end{array}$ & $\begin{array}{c}-0.001 \\
(-0.770)\end{array}$ & $\begin{array}{c}0.001 \\
(0.740)\end{array}$ & $\begin{array}{l}0.0003 \\
(0.310)\end{array}$ & $\begin{array}{c}-0.001 \\
(-1.320)\end{array}$ & $\begin{array}{l}-0.001 * \\
(-1.900)\end{array}$ & $\begin{array}{c}-0.001 \\
(-1.560)\end{array}$ & $\begin{array}{c}-0.004 \\
(-0.880)\end{array}$ & $\begin{array}{c}-0.003 \\
(-0.810)\end{array}$ & $\begin{array}{c}-0.004 \\
(-0.930)\end{array}$ & $\begin{array}{c}-0.178 \\
(-0.900)\end{array}$ & 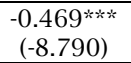 & 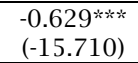 \\
\hline S & $\begin{array}{c}-0.005 \\
(-1.430) \\
\end{array}$ & $\begin{array}{c}-0.005 \\
(-1.570) \\
\end{array}$ & $\begin{array}{c}-0.004 \\
(-1.260) \\
\end{array}$ & $\begin{array}{l}0.056^{* \cdots *} \\
(2.140) \\
\end{array}$ & $\begin{array}{c}0.023 \\
(0.680) \\
\end{array}$ & $\begin{array}{c}0.023 \\
(0.760) \\
\end{array}$ & $\begin{array}{c}0.002 \\
(0.680) \\
\end{array}$ & $\begin{array}{l}0.0004 \\
(0.190) \\
\end{array}$ & $\begin{array}{c}0.001 \\
(0.490) \\
\end{array}$ & $\begin{array}{c}-0.001 \\
(-0.100) \\
\end{array}$ & $\begin{array}{c}0.001 \\
(0.070) \\
\end{array}$ & $\begin{array}{c}-0.001 \\
(-0.080) \\
\end{array}$ & $\begin{array}{l}-0.248^{* * *} \\
(-2.170) \\
\end{array}$ & $\begin{array}{l}-0.222 * * \\
(-2.190) \\
\end{array}$ & $\begin{array}{c}-0.280^{* \cdots * *} \\
(-3.280) \\
\end{array}$ \\
\hline $\mathrm{CI}$ & 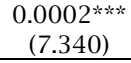 & $\begin{array}{c}0.0002^{*} * * * \\
(11.260)\end{array}$ & $\begin{array}{c}0.0002^{*}+* * \\
(7.400)\end{array}$ & $\begin{array}{l}0.0001 \\
(0.820) \\
\end{array}$ & $\begin{array}{l}-0.0001 \\
(-0.860) \\
\end{array}$ & $\begin{array}{l}-0.0001 \\
(-0.910) \\
\end{array}$ & $\begin{array}{c}-0.0002 \\
(-6.540) \\
\end{array}$ & $\begin{array}{l}-0.0002 \\
(-6.950) \\
\end{array}$ & $\begin{array}{l}-0.0002 \\
(-6.850) \\
\end{array}$ & $\begin{array}{l}-0.001^{* * * * *} \\
(-14.580)\end{array}$ & 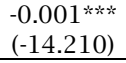 & 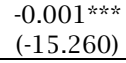 & $\begin{array}{c}-0.0002 \\
(-0.200) \\
\end{array}$ & $\begin{array}{l}-0.0003 \\
(-0.230) \\
\end{array}$ & $\begin{array}{l}-0.0003 \\
(-0.250) \\
\end{array}$ \\
\hline C & $\begin{array}{c}0.087 \\
(1.310) \\
\end{array}$ & $\begin{array}{c}0.039 \\
(0.440) \\
\end{array}$ & $\begin{array}{c}0.095 \\
(0.830) \\
\end{array}$ & $\begin{array}{c}-0.534 \\
(-0.890)\end{array}$ & $\begin{array}{c}-0.032 \\
(-0.050)\end{array}$ & $\begin{array}{c}0.712 \\
(0.860)\end{array}$ & $\begin{array}{c}-0.008 \\
(-0.150)\end{array}$ & $\begin{array}{c}0.035 \\
(0.600)\end{array}$ & $\begin{array}{c}-0.030 \\
(-0.900)\end{array}$ & $\begin{array}{c}-0.063 \\
(-0.240) \\
\end{array}$ & $\begin{array}{c}-0.297 \\
(-1.150) \\
\end{array}$ & $\begin{array}{c}-0.002 \\
(-0.010)\end{array}$ & $\begin{array}{c}17.439 * \ldots=0 \\
(2.630)\end{array}$ & $\begin{array}{c}-2.587 \\
(-0.720)\end{array}$ & 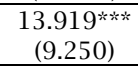 \\
\hline $\begin{array}{l}\text { Sargan } \\
P \text {-value }\end{array}$ & 8.718 & 10.094 & 7.096 & 3.133 & 9.459 & 5.544 & 6.765 & 5.295 & 5.697 & 2.260 & 2.625 & 3.030 & 4.040 & 10.283 & 9.441 \\
\hline $\begin{array}{l}P \text {-value } \\
\text { AR1 }\end{array}$ & 0.121 & 0.073 & 0.214 & 0.680 & 0.092 & 0.353 & 0.239 & 0.381 & 0.337 & 0.812 & 0.758 & 0.695 & 0.544 & 0.068 & 0.093 \\
\hline \begin{tabular}{|l|} 
AR1 \\
$P$-value
\end{tabular} & $\frac{-2.373}{0.018}$ & -2.401 & -2.242 & -1.177 & -1.128 & -1.104 & -1.249 & -1.268 & -1.245 & -2.197 & -2.166 & -2.259 & -1.003 & -1.004 & -0.897 \\
\hline$P$-value & 0.018 & 0.016 & 0.025 & 0.239 & 0.259 & 0.270 & 0.212 & 0.205 & 0.213 & 0.028 & 0.030 & 0.024 & 0.316 & 0.315 & 0.370 \\
\hline \begin{tabular}{|l} 
AR2 \\
$P$-value
\end{tabular} & 0.611 & 0.587 & 0.610 & -0.677 & -0.827 & -0.901 & -0.419 & -0.412 & -0.404 & -0.956 & -0.960 & -0.958 & -1.358 & -1.305 & -1.279 \\
\hline$P$-value & 0.541 & 0.577 & 0.542 & 0.498 & 0.408 & 0.368 & 0.675 & 0.680 & 0.686 & 0.339 & 0.337 & 0.380 & 0.175 & 0.192 & 0.201 \\
\hline
\end{tabular}

Notes: L1. = first lagged value of dependent variable; $L 2 .=$ second lagged value of independent variable; $C=$ constant; $* * * * * * *$, and ** represent significance level of $1 \%$, $5 \%$ and $10 \% ; C A R=$ capital adequacy ratio; $L C R=$ liquidity coverage ratio; $N P L=$ non-performing loan; $\sigma R O E=$ volatility in return on equity; $\sigma R O A=$ volatility in return on assets; $F B=$ foreign banks; $P B=$ public banks; $P V B=$ private banks, $D=$ diversification, $R G=$ revenue growth, $R O A=$ return on assets; $S=$ bank size; $C I=$ cost to income ratio; $C=$ constant; Sargan = test for overidentifying restrictions; AR1 = Arellano-Bond first order autocorrelation: $A R 2=$ Arellano-Bond second order autocorrelation. 
Findings also reveal that revenue concentration has an insignificant impact on risk-taking behavior except for credit risk where it shows a significant negative impact in case of foreign and publicly owned banks. Insignificant impact justifies that banks manage diversified incomes efficiently and they do not affect their risk-taking behavior. Findings are in line with the results of Weiß, Bostandzic, and Neumann (2014). The control variable of our study, return on assets, reveals that it decreases capital adequacy ratio significantly in case of foreign banks only, whereas, it decreases credit risk in case of a publicly owned bank. Further, return on assets has a significant negative impact on the volatility of return on assets in case of publicly and privately owned banks. However, it shows an insignificant impact in case of other risk-taking behaviors. Banks size has a significant and negative impact on the volatility of return on assets only. However, it does not affect other risk-taking behavior of banks which suggests that whether they are foreign, privately or publicly owned banks, size is irrelevant for their risk because risk depends on their business activities. Cost to income ratio has a significant positive influence on capital adequacy ratio, whereas, it has a significant negative influence on the volatility of return on equity.

Positive impact indicates that when the cost to income ratio is high, it shows the inefficiency of banks, which increases bank risk, and vice versa. This reason is supported by Ghosh, Nachane, Narain, and Sahoo (2003). However, a negative impact on return volatility suggests that when banks decrease their cost to income ratio, their return volatility increases. It shows the inefficiency of banks to manage return volatility when controlling cost to income ratio.

In Table 6, we estimate the impact of ownership structure on risk-taking behavior with country-wise analysis from 2011 to 2018. In this regard, the findings reveal mixed outputs depending on the nature and regulation of the banking business in each country. Results justify that all forms of ownerships significantly affect the level of risk-taking behavior of banks in selected countries, which implies that forms of ownership matter for determining capital adequacy ratio. Further, results reveal that publicly owned banks in Pakistan increase the capital adequacy ratio. However, in the context of India and Bangladesh, publicly owned banks have a significant and negative impact on capital adequacy ratio. Further, significant and positive relationship between private banks and risk measures shows very risky behavior of privately owned banks in Bangladesh. Indeed, private banks are naturally aggressive with the investment decision. Actually, capital adequacy ratio is weighted credit exposure and generally private and foreign banks are involved in high credit risk exposure and this is consistent with our result across Pakistan, India, and Bangladesh. Public and privately owned banks have significant impacts on liquidity risk behavior in Pakistan, India, and Bangladesh. In contrast, the significant relationship of private banks shows a high level of liquidity risk while a significant impact of publicly owned banks shows a low level of liquidity risk pattern in India.

It is a fact that privately owned banks have a high volume of business in India as compared to Pakistan and Bangladesh. Indeed, it is a possibility that privately owned banks manage their liquidity risk in India. Ownership structure significantly affects non-performing loans for Pakistan, India, and Bangladesh. Furthermore, we find that publicly and privately owned banks have a significant influence on risk behavior with return volatility in South Asian countries. In addition, findings reveal that in general, foreign ownership reveals varying effects on the risk-taking behavior of Pakistan and India. However, in Bangladesh, foreign ownership has a significant impact on the risk-taking behavior of banks due to more stability in the political situation. This stability helps foreign investors to invest more funds in banks operating in Bangladesh. 
Table 6. Two-step system dynamic panel regression analysis (country-wise analysis) (Part 1)

\begin{tabular}{|c|c|c|c|c|c|c|c|c|c|c|c|c|c|c|c|}
\hline$P K$ & CAR & CAR & CAR & $L C R$ & $L C R$ & $L C R$ & NPL & $N P L$ & $N P L$ & $\delta R O E$ & $\delta R O E$ & $\delta R O E$ & $\delta R O A$ & $\delta R O A$ & $\delta R O A$ \\
\hline L1. & $\begin{array}{c}0.786^{* * * *} \\
(4.280)\end{array}$ & $\begin{array}{c}1.194^{\text {***** }} \\
(3.330)\end{array}$ & 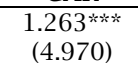 & $\begin{array}{c}0.613^{* * * *} \\
(4.590)\end{array}$ & $\begin{array}{c}0.726^{* * * *} \\
(3.850)\end{array}$ & $\begin{array}{l}0.503^{\text {**** }} \\
(2.400)\end{array}$ & $\begin{array}{c}0.698^{* \ldots * * \mathrm{k}} \\
(5.110)\end{array}$ & $\begin{array}{c}0.890^{* * * *} \\
(5.970)\end{array}$ & $\begin{array}{c}0.870^{* \cdots * * *} \\
(6.410)\end{array}$ & $\begin{array}{c}0.346^{* \ldots * *} \\
(6.510)\end{array}$ & $\begin{array}{c}-0.145 \\
(-1.540)\end{array}$ & $\begin{array}{l}0.113^{* * * *} \\
(2.520)\end{array}$ & 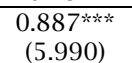 & $\begin{array}{l}0.726^{* \text { *n:* }} \\
(11.580)\end{array}$ & $\begin{array}{c}0.698^{* \ldots * * *} \\
(7.990)\end{array}$ \\
\hline L2. & $\begin{array}{c}-0.465 \\
(-1.570)\end{array}$ & $\begin{array}{c}0.002 \\
(0.030)\end{array}$ & $\begin{array}{c}-0.034 \\
(-0.320)\end{array}$ & $\begin{array}{l}0.279^{*} \\
(1.820)\end{array}$ & $\begin{array}{l}0.211^{*} \\
(1.730)\end{array}$ & $\begin{array}{c}0.274 \\
(2.080)\end{array}$ & $\begin{array}{c}0.077 \\
(0.740)\end{array}$ & $\begin{array}{c}0.080 \\
(0.980)\end{array}$ & $\begin{array}{c}0.054 \\
(0.670)\end{array}$ & $\begin{array}{l}-0.279^{* \cdots * * *} \\
(-4.480)\end{array}$ & $\begin{array}{c}-0.293 \\
(-1.010)\end{array}$ & $\begin{array}{c}-0.526^{* \ldots * *} \\
(-8.420)\end{array}$ & $\begin{array}{c}-0.385 \\
(-1.520)\end{array}$ & $\begin{array}{l}-0.519 \% * * \\
(-7.560)\end{array}$ & $\begin{array}{c}-0.490^{* * * *} \\
(-6.810)\end{array}$ \\
\hline FB & $\begin{array}{c}0.379^{* * * *} \\
(2.890) \\
\end{array}$ & --- & --- & $\begin{array}{c}0.070 \\
(0.030) \\
\end{array}$ & --- & --- & $\begin{array}{l}-1.459^{*} \\
(-1.740)\end{array}$ & --- & --.- & $\begin{array}{c}-0.861 \\
(-1.320) \\
\end{array}$ & --.- & --- & $\begin{array}{l}-25.528 \\
(-0.540) \\
\end{array}$ & --- & --- \\
\hline PB & $\cdots-$ & $\begin{array}{l}0.067^{*} \\
(1.880)\end{array}$ & --- & --- & $\begin{array}{l}0.182^{* * *} \\
(2.280)\end{array}$ & ---- & $-\cdots-$ & $\begin{array}{l}-0.480^{* * *} \\
(-2.120) \\
\end{array}$ & --- & $-\cdots-$ & $\begin{array}{l}1.897^{* * * * *} \\
(10.110)\end{array}$ & --- & ---- & $\begin{array}{c}16.516^{* * * *} \\
(24.180)\end{array}$ & --- \\
\hline PVB & --- & ---- & $\begin{array}{c}-0.364^{* \ldots * *} \text { * } \\
(-3.280) \\
\end{array}$ & --- & --- & $\begin{array}{l}0.750^{* * *} \\
(3.600)\end{array}$ & ---- & ---- & $\begin{array}{l}0.316^{*} \\
(1.870)\end{array}$ & --- & --- & 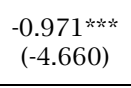 & ---- & --- & $\begin{array}{l}22.623^{* * * * *} \\
(-25.010) \\
\end{array}$ \\
\hline $\mathrm{D}$ & 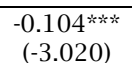 & $\begin{array}{l}-0.155^{*} \\
(-1.680)\end{array}$ & $\begin{array}{l}-0.164^{* * *} \\
(-1.960)\end{array}$ & $\begin{array}{c}0.086 \\
(1.370)\end{array}$ & $\begin{array}{c}0.089 \\
(1.560)\end{array}$ & $\begin{array}{c}0.073 \\
(1.310)\end{array}$ & $\begin{array}{c}0.055 \\
(0.410)\end{array}$ & $\begin{array}{c}0.109 \\
(0.870)\end{array}$ & $\begin{array}{c}0.119 \\
(1.030)\end{array}$ & $\begin{array}{l}0.671^{*} \\
(1.820)\end{array}$ & $\begin{array}{l}0.109^{*} \\
(1.750)\end{array}$ & $\begin{array}{c}0.127 \\
(1.430)\end{array}$ & $\begin{array}{c}-0.248 \\
(-0.190)\end{array}$ & $\begin{array}{c}0.504 \\
(0.730)\end{array}$ & $\begin{array}{c}0.239 \\
(0.350)\end{array}$ \\
\hline RG & $\begin{array}{c}-0.016 \\
(-0.310)\end{array}$ & $\begin{array}{c}-0.041 \\
(-1.070)\end{array}$ & $\begin{array}{l}-0.071^{*} \\
(-1.720)\end{array}$ & $\begin{array}{c}0.011 \\
(0.200)\end{array}$ & $\begin{array}{c}-0.015 \\
(-0.250)\end{array}$ & $\begin{array}{c}-0.060 \\
(-1.000)\end{array}$ & $\begin{array}{c}-0.125 \\
(-1.270)\end{array}$ & $\begin{array}{c}-0.073 \\
(-0.730)\end{array}$ & $\begin{array}{c}-0.091 \\
(-0.910)\end{array}$ & $\begin{array}{c}0.186 \\
(1.370)\end{array}$ & $\begin{array}{c}0.116 \\
(1.040)\end{array}$ & $\begin{array}{c}0.085 \\
(0.530)\end{array}$ & $\begin{array}{c}0.110 \\
(0.360)\end{array}$ & $\begin{array}{c}0.051 \\
(0.240)\end{array}$ & $\begin{array}{c}0.001 \\
(0.010)\end{array}$ \\
\hline ROA & $\begin{array}{c}-0.001 \\
(-1.150) \\
\end{array}$ & $\begin{array}{c}-0.002 \\
(-2.670) \\
\end{array}$ & $\begin{array}{l}-0.002^{* * * * *} \\
(-4.300)\end{array}$ & $\begin{array}{c}-0.002 \\
(-1.500) \\
\end{array}$ & $\begin{array}{c}-0.001 \\
(-0.790) \\
\end{array}$ & $\begin{array}{c}-0.001 \\
(-0.990) \\
\end{array}$ & $\begin{array}{c}-0.001 \\
(-0.810) \\
\end{array}$ & $\begin{array}{c}-0.002 \\
(-1.060) \\
\end{array}$ & $\begin{array}{c}-0.002 \\
(-1.080) \\
\end{array}$ & $\begin{array}{c}-0.003 \\
(-0.600) \\
\end{array}$ & $\begin{array}{c}-0.001 \\
(-0.530) \\
\end{array}$ & $\begin{array}{c}-0.004 \\
(-0.730) \\
\end{array}$ & 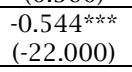 & $\begin{array}{l}-0.561^{* \ldots \ldots * m} \\
(-58.630)\end{array}$ & $\begin{array}{l}-0.554^{\ldots \ldots \ldots} \ldots \\
(-30.580)\end{array}$ \\
\hline S & $\begin{array}{c}0.026 \\
(1.060)\end{array}$ & $\begin{array}{c}-0.003 \\
(-0.150)\end{array}$ & $\begin{array}{l}0.053^{\text {*** }} \\
(2.290)\end{array}$ & $\begin{array}{c}-0.003 \\
(-0.150)\end{array}$ & $\begin{array}{c}-0.040 \\
(-1.440)\end{array}$ & $\begin{array}{c}-0.024 \\
(-0.730)\end{array}$ & $\begin{array}{l}0.030^{*} \\
(1.660)\end{array}$ & $\begin{array}{c}0.012 \\
(0.990)\end{array}$ & $\begin{array}{c}0.014 \\
(1.130)\end{array}$ & $\begin{array}{c}-0.123 \\
(-1.110)\end{array}$ & $\begin{array}{l}-0.129^{*} \\
(-1.930)\end{array}$ & $\begin{array}{c}-0.167 \\
(-1.490)\end{array}$ & $\begin{array}{c}-0.309 \\
(-0.800)\end{array}$ & $\begin{array}{c}-0.072 \\
(-0.360)\end{array}$ & $\begin{array}{c}-0.067 \\
(-0.230)\end{array}$ \\
\hline $\mathrm{CI}$ & $\begin{array}{c}0.0002^{* \ldots * *} \\
(10.140)\end{array}$ & $\begin{array}{c}0.0003^{\text {前前 }} \\
(4.440)\end{array}$ & $\begin{array}{c}0.0003^{\text {前* }} \\
(5.940)\end{array}$ & 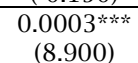 & $\begin{array}{c}0.0003^{* \ldots+k} \\
(6.930)\end{array}$ & 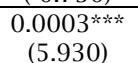 & $\begin{array}{c}-0.0001^{* \ldots * *} \\
(-2.800)\end{array}$ & $\begin{array}{l}-0.0002 \\
(-2.970)\end{array}$ & $\begin{array}{l}-0.0001 \\
(-2.910)\end{array}$ & 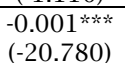 & 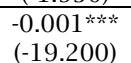 & 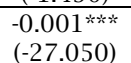 & $\begin{array}{l}-0.0001 \\
(-0.050)\end{array}$ & $\begin{array}{l}-0.0001 \\
(0.929)\end{array}$ & $\begin{array}{c}-0.0001 \\
(-0.110)\end{array}$ \\
\hline C & $\begin{array}{c}-0.239 \\
(-0.590)\end{array}$ & $\begin{array}{c}0.055 \\
(0.160)\end{array}$ & $\begin{array}{l}-0.482^{*} \\
(-1.640)\end{array}$ & $\begin{array}{c}0.072 \\
(0.210)\end{array}$ & $\begin{array}{c}0.497 \\
(1.020)\end{array}$ & $\begin{array}{c}-0.063 \\
(-0.080)\end{array}$ & $\begin{array}{c}-0.204 \\
(-1.080)\end{array}$ & $\begin{array}{c}-0.106 \\
(-0.650)\end{array}$ & $\begin{array}{l}-0.441^{* * *} \\
(-2.330)\end{array}$ & $\begin{array}{c}1.862 \\
(1.330)\end{array}$ & $\begin{array}{l}1.687^{*} \\
(1.810)\end{array}$ & $\begin{array}{l}3.395 \text { * } \\
(2.200)\end{array}$ & $\begin{array}{l}9.594^{* * *} \\
(2.380)\end{array}$ & $\begin{array}{c}-2.350 \\
(-0.810)\end{array}$ & 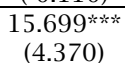 \\
\hline Sargan & 2.287 & 5.208 & 2.896 & 4.243 & 10.763 & 8.640 & 4.826 & 7.433 & 6.893 & 6.592 & 6.425 & 8.024 & 3.640 & 3.756 & 3.337 \\
\hline$P$-value & 0.808 & 0.391 & 0.716 & 0.515 & 0.056 & 0.124 & 0.438 & 0.190 & 0.229 & 0.253 & 0.267 & 0.155 & 0.602 & 0.585 & 0.648 \\
\hline AR1 & -1.528 & -1.424 & -1.501 & -1.324 & -0.921 & -0.537 & -1.096 & -1.137 & -1.137 & -0.929 & -0.735 & -0.932 & -0.947 & -0.953 & -0.944 \\
\hline$P$-value & 0.127 & 0.155 & 0.133 & 0.186 & 0.357 & 0.592 & 0.273 & 0.255 & 0.255 & 0.353 & 0.462 & 0.352 & 0.344 & 0.341 & 0.345 \\
\hline AR2 & 1.002 & 0.971 & 1.040 & -0.782 & -0.377 & -0.048 & -0.582 & -0.717 & -0.667 & -0.752 & 1.184 & 0.406 & -1.396 & -1.332 & -1.314 \\
\hline$P$-value & 0.316 & 0.331 & 0.298 & 0.434 & 0.706 & 0.962 & 0.560 & 0.473 & 0.505 & 0.452 & 0.236 & 0.685 & 0.163 & 0.183 & 0.189 \\
\hline$I N D$ & CAR & CAR & $C A R$ & $I C R$ & $I C R$ & $I C R$ & $N P I_{2}$ & $N P I_{1}$ & $N P I_{1}$ & $S R O F$ & $\delta R O F$ & $\delta R O F$ & Aroa & $\delta R O A$ & $\delta R O A$ \\
\hline L1. & $\begin{array}{c}-0.072 \\
(-0.250)\end{array}$ & $\begin{array}{c}-0.556 \\
(-1.550)\end{array}$ & $\begin{array}{l}0.694^{* \cdots} \\
(1.990)\end{array}$ & $\begin{array}{c}0.010^{* \ldots * * *} \\
(1.980)\end{array}$ & $\begin{array}{c}-0.684 \\
(-0.440)\end{array}$ & $\begin{array}{c}-1.452 \\
(-0.930)\end{array}$ & 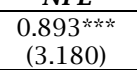 & $\begin{array}{c}-0.289 \\
(-0.870)\end{array}$ & $\begin{array}{c}0.298 \\
(0.590)\end{array}$ & 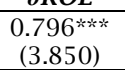 & $\begin{array}{c}0.167 \\
(1.180)\end{array}$ & $\begin{array}{c}0.748^{\text {**:** }} \\
(8.640)\end{array}$ & $\begin{array}{l}-1.016^{* \ldots \ldots * k} \\
(134.920)\end{array}$ & $\begin{array}{l}-1.008^{* \ldots * * * \ldots} \\
(-90.160)\end{array}$ & $\begin{array}{l}-1.019 * \cdots * * * * \\
(127.990)\end{array}$ \\
\hline L2. & $\begin{array}{c}-0.028 \\
(-0.360)\end{array}$ & $\begin{array}{c}0.026 \\
(0.360)\end{array}$ & $\begin{array}{c}0.012 \\
(0.080)\end{array}$ & 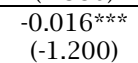 & $\begin{array}{c}-0.701 \\
(-0.470)\end{array}$ & $\begin{array}{c}-1.422 \\
(-0.950)\end{array}$ & $\begin{array}{l}0.269^{* * *} \\
(2.350)\end{array}$ & $\begin{array}{c}0.333^{* * * *} \\
(3.210)\end{array}$ & $\begin{array}{l}0.295^{* * *} \\
(2.500)\end{array}$ & 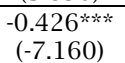 & $\begin{array}{c}-0.166 \\
(-1.250)\end{array}$ & $\begin{array}{l}-0.185^{* * *} \\
(-2.540)\end{array}$ & $\begin{array}{l}-0.0003 \\
(-0.290)\end{array}$ & $\begin{array}{c}-0.002 \\
(-0.820)\end{array}$ & $\begin{array}{c}0.001 \\
(0.410)\end{array}$ \\
\hline $\mathrm{FB}$ & $\begin{array}{c}0.056^{* \ldots * *} \\
(2.810)\end{array}$ & --- & --.- & $\begin{array}{c}-0.046 \\
(-0.050)\end{array}$ & --- & --- & $\begin{array}{l}-0.069^{*} \\
(-1.820)\end{array}$ & --- & -.- & $\begin{array}{c}2.453 \\
(0.860)\end{array}$ & --- & -.-- & $\begin{array}{c}0.019^{* * * * *} \\
(3.580)\end{array}$ & ---- & -.-- \\
\hline PB & --- & $\begin{array}{c}-0.073^{\ldots \ldots * *} \\
(-2.920)\end{array}$ & --- & --- & $\begin{array}{l}3.503^{\text {****** }} \\
(4.200)\end{array}$ & --- & --- & $\begin{array}{l}1.186^{* * *} \\
(4.620)\end{array}$ & $-\cdots-$ & --- & $\begin{array}{c}-2.362^{* * * *} \\
(-3.930)\end{array}$ & --- & --- & $\begin{array}{l}-0.022^{* * *} \\
(-2.190)\end{array}$ & --- \\
\hline PVB & --- & --- & $\begin{array}{l}-0.101 * \\
(-1.740)\end{array}$ & ---- & --- & $\begin{array}{c}-4.637^{* \cdots *} \\
(-2.740)\end{array}$ & ---- & ---- & $\begin{array}{l}-0.221 * \\
(-2.380) \\
\end{array}$ & ---- & ---- & $\begin{array}{l}0.073^{*} \\
(3.390)\end{array}$ & ---- & ---- & $\begin{array}{l}-0.216^{*} \\
(-3.060) \\
\end{array}$ \\
\hline D & $\begin{array}{c}0.007 \\
(0.140)\end{array}$ & $\begin{array}{c}-0.019 \\
(-0.280)\end{array}$ & $\begin{array}{c}0.064 \\
(1.150)\end{array}$ & $\begin{array}{c}-0.061 \\
(-0.130)\end{array}$ & $\begin{array}{c}0.477 \\
(0.850)\end{array}$ & $\begin{array}{c}-0.829 \\
(-0.990)\end{array}$ & $\begin{array}{c}0.598^{\text {***** }} \\
(2.970)\end{array}$ & $\begin{array}{c}0.891^{* * * *} \\
(4.880)\end{array}$ & $\begin{array}{l}0.629^{* * * *} \\
(2.960)\end{array}$ & 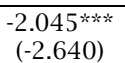 & $\begin{array}{c}1.006 \\
(0.770)\end{array}$ & $\begin{array}{c}-0.513 \\
(-0.490)\end{array}$ & 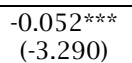 & $\begin{array}{c}-0.041^{* * * * *} \\
(-3.060)\end{array}$ & 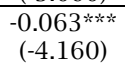 \\
\hline RG & $\begin{array}{c}0.031 \\
(1.140)\end{array}$ & $\begin{array}{l}0.056^{*} \\
(1.840)\end{array}$ & $\begin{array}{c}-0.021 \\
(-0.690)\end{array}$ & $\begin{array}{c}-0.034 \\
(-0.130)\end{array}$ & $\begin{array}{c}0.168 \\
(0.490)\end{array}$ & $\begin{array}{c}-0.165 \\
(-0.380)\end{array}$ & $\begin{array}{c}0.014 \\
(0.180)\end{array}$ & $\begin{array}{c}-0.109 \\
(-1.010)\end{array}$ & $\begin{array}{c}-0.133 \\
(-1.360)\end{array}$ & $\begin{array}{c}0.440 \\
(0.630)\end{array}$ & $\begin{array}{c}-0.771 \\
(-0.970)\end{array}$ & $\begin{array}{c}0.148 \\
(0.190)\end{array}$ & $\begin{array}{c}-0.001 \\
(-0.060)\end{array}$ & $\begin{array}{c}0.002 \\
(0.200)\end{array}$ & $\begin{array}{c}0.004 \\
(0.390)\end{array}$ \\
\hline ROA & $\begin{array}{c}-0.002 \\
(-0.610)\end{array}$ & $\begin{array}{c}0.002 \\
(0.340)\end{array}$ & $\begin{array}{c}-0.004 \\
(-1.000)\end{array}$ & $\begin{array}{c}0.020 \\
(0.260)\end{array}$ & $\begin{array}{c}-0.021 \\
(-0.280)\end{array}$ & $\begin{array}{c}0.028 \\
(0.330)\end{array}$ & $\begin{array}{c}0.005 \\
(0.500)\end{array}$ & $\begin{array}{c}0.002 \\
(0.460)\end{array}$ & $\begin{array}{l}0.020^{* * *} \\
(1.990)\end{array}$ & $\begin{array}{l}0.180 \ldots * \\
(2.540)\end{array}$ & $\begin{array}{c}0.078 \\
(0.990)\end{array}$ & $\begin{array}{c}-0.006 \\
(-0.080)\end{array}$ & 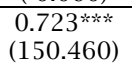 & 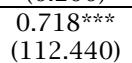 & 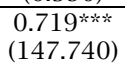 \\
\hline
\end{tabular}


Table 6. Two-step system dynamic panel regression analysis (country-wise analysis) (Part 2)

\begin{tabular}{|c|c|c|c|c|c|c|c|c|c|c|c|c|c|c|c|}
\hline IND & CAR & CAR & CAR & $L C R$ & $L C R$ & $L C R$ & NPL & NPL & $N P L$ & $\delta R O E$ & $\delta R O E$ & $\delta R O E$ & Aroa & $\delta R O A$ & $\delta R O A$ \\
\hline S & $\begin{array}{c}-0.001 \\
(-0.900)\end{array}$ & $\begin{array}{c}0.001 \\
(0.450)\end{array}$ & $\begin{array}{l}-0.003^{* * *} \\
(-1.970)\end{array}$ & $\begin{array}{c}0.008 \\
(0.310)\end{array}$ & $\begin{array}{c}-0.008 \\
(-0.230)\end{array}$ & $\begin{array}{c}0.009 \\
(0.290)\end{array}$ & $\begin{array}{c}0.003 \\
(0.850)\end{array}$ & $\begin{array}{c}0.001 \\
(0.390)\end{array}$ & $\begin{array}{l}0.009^{* * *} \\
(2.280)\end{array}$ & $\begin{array}{c}0.067^{\text {****** }} \\
(2.590)\end{array}$ & $\begin{array}{c}0.027 \\
(0.880)\end{array}$ & $\begin{array}{c}-0.005 \\
(-0.150) \\
\end{array}$ & $\begin{array}{c}0.005^{* \ldots * * *} \\
(3.980)\end{array}$ & $\begin{array}{c}0.004^{* * * * *} \\
(2.600)\end{array}$ & $\begin{array}{c}0.003^{* * * * k} \\
(2.580)\end{array}$ \\
\hline CI & $\begin{array}{l}0.0001 \\
(0.080)\end{array}$ & $\begin{array}{c}0.001 \\
(1.460)\end{array}$ & $\begin{array}{c}-0.001 \\
(-1.350)\end{array}$ & $\begin{array}{c}-0.020^{* \ldots * *} \\
(-4.610)\end{array}$ & $\begin{array}{c}-0.032 \\
(-0.210)\end{array}$ & $\begin{array}{c}0.054 \\
(0.370)\end{array}$ & $\begin{array}{c}0.001 \\
(0.750)\end{array}$ & $\begin{array}{c}0.001 \\
(1.060)\end{array}$ & $\begin{array}{l}0.002^{*} \\
(1.790)\end{array}$ & $\begin{array}{l}0.017^{\text {*** }} \\
(2.380)\end{array}$ & $\begin{array}{c}0.009 \\
(0.910)\end{array}$ & $\begin{array}{c}-0.002 \\
(-0.150)\end{array}$ & $\begin{array}{l}0.002^{* * * * *} \\
(12.900)\end{array}$ & $\begin{array}{c}0.002^{* \cdots * *} \\
(7.050)\end{array}$ & $\begin{array}{l}0.001^{* * * *} \\
(15.760)\end{array}$ \\
\hline C & $\begin{array}{c}0.152^{* * * *} \\
(3.740)\end{array}$ & $\begin{array}{c}0.214^{* * * *} \\
(4.090)\end{array}$ & $\begin{array}{c}0.122 \\
(2.360) \\
\end{array}$ & $\begin{array}{c}-0.110 \\
(-0.260) \\
\end{array}$ & $\begin{array}{l}-1.621^{*} \\
(-1.900)\end{array}$ & $\begin{array}{l}1.323^{*} \\
(1.710)\end{array}$ & $\begin{array}{c}-0.065 \\
(-0.990) \\
\end{array}$ & $\begin{array}{c}-0.102 \\
(-0.660)\end{array}$ & $\begin{array}{c}-0.162^{* \ldots *} \\
(-3.350)\end{array}$ & $\begin{array}{l}-1.809^{*} \\
(-1.890)\end{array}$ & $\begin{array}{c}0.830 \\
(1.510)\end{array}$ & $\begin{array}{c}0.152 \\
(0.210)\end{array}$ & $\begin{array}{c}-0.104^{* \ldots * k} \\
(-4.180)\end{array}$ & $\begin{array}{l}-0.062 \ldots * \\
(-2.570)\end{array}$ & $\begin{array}{c}-0.058 * * * * \\
(-2.790)\end{array}$ \\
\hline Sargan & 5.810 & 5.109 & 7.331 & 6.823 & 0.672 & 1.842 & 9.424 & 2.605 & 7.470 & 8.204 & 4.028 & 5.983 & 2.108 & 4.796 & 4.332 \\
\hline$P$-value & 0.325 & 0.403 & 0.197 & 0.413 & 0.985 & 0.871 & 0.093 & 0.761 & 0.188 & 0.145 & 0.545 & 0.308 & 0.834 & 0.441 & 0.503 \\
\hline AR1 & -0.990 & -0.434 & -1.990 & -1.007 & -1.161 & -1.332 & -2.572 & -1.649 & -1.791 & -1.028 & -1.671 & -1.309 & -1.027 & -1.018 & -1.010 \\
\hline$P$-value & 0.322 & 0.664 & 0.047 & 0.314 & 0.246 & 0.183 & 0.010 & 0.092 & 0.073 & 0.304 & 0.301 & 0.191 & 0.304 & 0.309 & 0.313 \\
\hline AR2 & 0.107 & -0.080 & 0.902 & 0.974 & -1.050 & 1.188 & 0.715 & 0.589 & 0.841 & -1.004 & -1.001 & -1.001 & -0.497 & 1.213 & -0.771 \\
\hline$P$-value & 0.915 & 0.936 & 0.367 & 0.330 & 0.294 & 0.235 & 0.475 & 0.556 & 0.400 & 0.315 & 0.317 & 0.317 & 0.617 & 0.225 & 0.441 \\
\hline$B D$ & CAR & CAR & CAR & $L C R$ & $L C R$ & $L C R$ & NPL & NPL & $N P L$ & $\delta R O E$ & $\delta R O E$ & $\delta R O E$ & $\delta R O A$ & $\delta R O A$ & $\delta R O A$ \\
\hline L1. & $\begin{array}{l}0.406^{*} \\
(1.930)\end{array}$ & $\begin{array}{l}0.806^{* * * *} \\
(10.560)\end{array}$ & 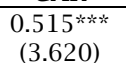 & $\begin{array}{c}-0.190^{*} \\
(-1.690)\end{array}$ & $\begin{array}{c}-0.072 \\
(-0.630)\end{array}$ & $\begin{array}{c}-0.053 \\
(-0.520)\end{array}$ & $\begin{array}{l}1.103^{* * * * k} \\
(4.180)\end{array}$ & $\begin{array}{c}0.983^{* * * *} \\
(5.790)\end{array}$ & $\begin{array}{l}1.012^{* * * * *} \\
(5.310)\end{array}$ & 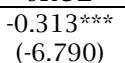 & 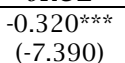 & 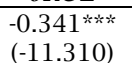 & 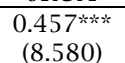 & 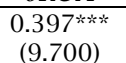 & $\begin{array}{c}0.294^{\text {****k }} \\
(6.700)\end{array}$ \\
\hline L2. & $\begin{array}{c}0.187^{* * * *} \\
(2.710)\end{array}$ & $\begin{array}{l}0.166^{* * *} \\
(2.420)\end{array}$ & $\begin{array}{c}-0.090 \\
(-1.260) \\
\end{array}$ & $\begin{array}{c}-0.216 \\
(-1.520) \\
\end{array}$ & $\begin{array}{c}-0.038 \\
(-0.270)\end{array}$ & $\begin{array}{c}-0.024 \\
(-0.190)\end{array}$ & $\begin{array}{c}-0.129 \\
(-1.530)\end{array}$ & $\begin{array}{c}-0.145 \\
(-1.010) \\
\end{array}$ & $\begin{array}{c}-0.122 \\
(-0.960) \\
\end{array}$ & $\begin{array}{l}-0.248^{* \ldots * * *} \\
(-4.560)\end{array}$ & 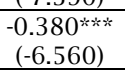 & $\begin{array}{l}-0.220 * * * * \\
(-4.770)\end{array}$ & 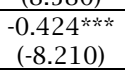 & 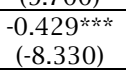 & $\begin{array}{l}-0.338^{* \cdots * * *} \\
(-6.650)\end{array}$ \\
\hline FB & $\begin{array}{l}-0.713^{*} \\
(-1.760)\end{array}$ & --- & --- & $\begin{array}{l}-2.336^{*} \\
(-1.830)\end{array}$ & --- & -.- & $\begin{array}{l}-0.044^{* * *} \\
(-3.450)\end{array}$ & --- & --- & $\begin{array}{l}-1.683^{* * *} \\
(-2.080)\end{array}$ & --- & --- & $\begin{array}{l}0.033^{* * *} \\
(1.910)\end{array}$ & --- & --- \\
\hline PB & ---- & $\begin{array}{l}-0.005^{*} \\
(-2.050)\end{array}$ & $\cdots--$ & ---- & $\begin{array}{l}1.209^{\text {** }} \\
(3.440)\end{array}$ & ---- & --- & $\begin{array}{c}0.016 \\
(0.260)\end{array}$ & ---- & --- & $\begin{array}{l}1.114^{*} \\
(1.680)\end{array}$ & ---- & --- & $\begin{array}{c}-0.044^{* \ldots * *} \\
(-3.250)\end{array}$ & --- \\
\hline PVB & $\cdots--$ & --.- & $\begin{array}{c}0.313^{* * * *} \\
(2.600)\end{array}$ & --- & --- & $\begin{array}{l}1.298^{\text {荻 }} \\
(4.680)\end{array}$ & ---- & ---- & $\begin{array}{l}-0.0003^{*} \\
(-2.010)\end{array}$ & --- & --- & $\begin{array}{c}2.087^{\text {***** }} \\
(2.570)\end{array}$ & --- & --- & $\begin{array}{c}0.096^{\text {***** }} \\
(3.760)\end{array}$ \\
\hline D & $\begin{array}{c}-0.076 \\
(-0.530) \\
\end{array}$ & $\begin{array}{c}0.150 \\
(1.010)\end{array}$ & $\begin{array}{c}-0.074 \\
(-0.460) \\
\end{array}$ & $\begin{array}{c}0.073 \\
(0.840)\end{array}$ & $\begin{array}{c}0.046 \\
(0.400)\end{array}$ & $\begin{array}{c}0.048 \\
(0.380)\end{array}$ & $\begin{array}{c}0.038 \\
(0.390)\end{array}$ & $\begin{array}{c}0.060 \\
(0.680)\end{array}$ & $\begin{array}{c}0.067 \\
(0.770) \\
\end{array}$ & $\begin{array}{c}-0.191 \\
(-0.490) \\
\end{array}$ & $\begin{array}{c}-0.397 \\
(-1.390) \\
\end{array}$ & $\begin{array}{c}-0.113 \\
(-0.900) \\
\end{array}$ & $\begin{array}{c}0.004 \\
(0.140)\end{array}$ & $\begin{array}{c}0.00004 \\
(0.000)\end{array}$ & $\begin{array}{c}-0.002 \\
(-0.100) \\
\end{array}$ \\
\hline RG & $\begin{array}{c}0.011 \\
(0.420)\end{array}$ & $\begin{array}{c}0.020 \\
(0.440)\end{array}$ & $\begin{array}{c}0.001 \\
(0.030)\end{array}$ & $\begin{array}{l}-0.132^{*} \\
(-1.920)\end{array}$ & $\begin{array}{c}-0.095 \\
(-1.510)\end{array}$ & $\begin{array}{c}-0.094 \\
(-1.490)\end{array}$ & $\begin{array}{c}-0.057 \\
(-1.520)\end{array}$ & $\begin{array}{l}-0.052^{*} \\
(-1.830)\end{array}$ & $\begin{array}{c}-0.053 \\
(-1.450)\end{array}$ & $\begin{array}{c}-0.004 \\
(-0.060)\end{array}$ & $\begin{array}{c}-0.004 \\
(-0.100)\end{array}$ & $\begin{array}{c}0.018 \\
(0.440)\end{array}$ & $\begin{array}{l}-0.030^{*} \\
(-1.740)\end{array}$ & $\begin{array}{l}-0.039 \text { *** } \\
(-2.230)\end{array}$ & $\begin{array}{l}-0.029^{* * * *} \\
(-2.700)\end{array}$ \\
\hline ROA & $\begin{array}{c}0.234 \\
(0.660)\end{array}$ & $\begin{array}{c}-0.239 \\
(-0.890)\end{array}$ & $\begin{array}{c}-0.374 \\
(-1.230)\end{array}$ & $\begin{array}{c}0.936 \\
(0.850)\end{array}$ & $\begin{array}{c}0.286 \\
(1.200)\end{array}$ & $\begin{array}{c}0.373 \\
(1.370)\end{array}$ & $\begin{array}{c}0.312 \\
(0.610)\end{array}$ & $\begin{array}{c}0.179 \\
(0.590)\end{array}$ & $\begin{array}{c}0.180 \\
(0.470)\end{array}$ & $\begin{array}{l}1.789^{* * * * *} \\
(4.890)\end{array}$ & $\begin{array}{c}1.631 \\
(1.380)\end{array}$ & $\begin{array}{c}-0.432 \\
(-0.420)\end{array}$ & $\begin{array}{l}0.543^{* \ldots * * *} \\
(14.610)\end{array}$ & $\begin{array}{l}0.419^{*} \cdots * * \\
(11.670)\end{array}$ & $\begin{array}{c}0.271^{* * * *} \\
(3.550)\end{array}$ \\
\hline S & $\begin{array}{c}0.013 \\
(0.770)\end{array}$ & $\begin{array}{l}-0.015^{*} \\
(-1.830)\end{array}$ & $\begin{array}{l}-0.026^{* * *} \\
(-2.250)\end{array}$ & $\begin{array}{c}0.040 \\
(0.870)\end{array}$ & $\begin{array}{c}0.013 \\
(1.240)\end{array}$ & $\begin{array}{c}0.016 \\
(1.390)\end{array}$ & $\begin{array}{c}0.007 \\
(0.400)\end{array}$ & $\begin{array}{c}0.002 \\
(0.200)\end{array}$ & $\begin{array}{c}0.001 \\
(0.120)\end{array}$ & $\begin{array}{l}0.073^{* * * *} \\
(5.000)\end{array}$ & $\begin{array}{c}0.067 \\
(1.360)\end{array}$ & $\begin{array}{c}-0.019 \\
(-0.450)\end{array}$ & $\begin{array}{c}0.001 \\
(0.460)\end{array}$ & $\begin{array}{l}-0.003^{* \ldots * *} \\
(-2.570)\end{array}$ & $\begin{array}{c}-0.008 \\
(-3.060)\end{array}$ \\
\hline CI & $\begin{array}{c}-0.003^{\ldots+\cdots * \ldots} \\
(-6.330)\end{array}$ & $\begin{array}{c}\left.-0.1 .003^{*}\right) \\
(-4.630)\end{array}$ & 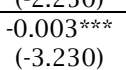 & $\begin{array}{l}0.0004 \\
(0.500)\end{array}$ & $\begin{array}{l}0.0003 \\
(0.570)\end{array}$ & $\begin{array}{l}0.0004 \\
(0.700)\end{array}$ & $\begin{array}{c}-0.002 \\
(-1.050) \\
\end{array}$ & $\begin{array}{c}-0.002 \\
(-0.630)\end{array}$ & $\begin{array}{c}-0.001 \\
(-0.620) \\
\end{array}$ & $\begin{array}{c}-0.001 \\
(-0.120)\end{array}$ & $\begin{array}{c}-0.003 \\
(-0.530) \\
\end{array}$ & $\begin{array}{c}-0.001 \\
(-0.210) \\
(\end{array}$ & $\begin{array}{l}0.0001 \\
(0.370) \\
\end{array}$ & $\begin{array}{l}0.0002 \\
(0.850) \\
\end{array}$ & $\begin{array}{l}0.0003 \\
(1.130) \\
\end{array}$ \\
\hline C & $\begin{array}{c}-0.066 \\
(-0.310)\end{array}$ & $\begin{array}{c}0.246 \\
(1.540)\end{array}$ & $\begin{array}{l}0.385^{* * *} \\
(2.140)\end{array}$ & $\begin{array}{c}0.167 \\
(0.640)\end{array}$ & $\begin{array}{c}0.153 \\
(0.970)\end{array}$ & $\begin{array}{c}-0.147 \\
(-0.300)\end{array}$ & $\begin{array}{c}-0.114 \\
(-0.340)\end{array}$ & $\begin{array}{c}-0.018 \\
(-0.110)\end{array}$ & $\begin{array}{c}-0.016 \\
(-0.060)\end{array}$ & $\begin{array}{l}-0.888^{* \ldots * *} \\
(-3.020)\end{array}$ & $\begin{array}{c}-1.134 \\
(-1.010)\end{array}$ & $\begin{array}{l}-0.723^{*} \\
(-1.720)\end{array}$ & $\begin{array}{c}0.002 \\
(0.090)\end{array}$ & $\begin{array}{c}0.087^{* * * *} \\
(2.730)\end{array}$ & $\begin{array}{c}0.101^{* * * *} \\
(2.700)\end{array}$ \\
\hline Sargan & 9.888 & 8.785 & 9.212 & 3.096 & 2.976 & 2.971 & 2.816 & 3.168 & 2.951 & 5.867 & 7.167 & 3.972 & 7.353 & 7.502 & 5.397 \\
\hline$P$-value & 0.079 & 0.118 & 0.1001 & 0.685 & 0.704 & 0.705 & 0.728 & 0.673 & 0.708 & 0.319 & 0.209 & 0.554 & 0.196 & 0.186 & 0.369 \\
\hline AR1 & -0.258 & -1.726 & -1.627 & -0.930 & -0.917 & -0.919 & -2.144 & -1.746 & -1.892 & -1.531 & -1.532 & -1.486 & -1.116 & -1.066 & -1.161 \\
\hline$P$-value & 0.796 & 0.084 & 0.104 & 0.352 & 0.359 & 0.358 & 0.032 & 0.081 & 0.059 & 0.126 & 0.126 & 0.137 & 0.264 & 0.286 & 0.245 \\
\hline AR2 & 0.604 & -1.479 & -0.466 & -0.810 & -0.791 & -0.763 & 1.364 & 1.146 & 1.338 & 0.757 & 1.724 & -1.257 & -1.606 & -1.759 & -1.633 \\
\hline$P$-value & 0.545 & $\begin{array}{l}0.139 \\
\end{array}$ & 0.641 & 0.418 & $\begin{array}{l}0.429 \\
\end{array}$ & 0.446 & 0.173 & 0.252 & 0.181 & 0.449 & 0.085 & 0.209 & 0.108 & 0.079 & 0.102 \\
\hline
\end{tabular}

level of $1 \%, 5 \%$ and $10 \% ; C A R=$ capital adequacy ratio; $L C R=$ liquidity coverage ratio; $N P L=$ non-performing loan; $\sigma R O E=$ volatility in return on equity; $\sigma R O A=$ ofolatility in return on assets; $F B=$ foreign banks; $P B=$ public banks; $P V B=$ private banks; $D=$ diversification; $R G=$ revenue growth; $R O A=$ return on assets; $S=$ bank size; $C I=$ cost to income ratio; $C=$ constant; Sargan = test for overidentifying restrictions; AR1 = Arellano-Bond first order autocorrelation; $A R 2=$ Arellano-Bond second order autocorrelation. 
Diversification, revenue growth, and return on assets are basic ingredients with the risk pattern of return on equity and return on assets volatility. Further, diversification has a significant relationship with the volatility of return on equity for Pakistan, while also having significant relationship with non-performing loans and volatility of return on assets for Bangladesh. However, it does not have any significant relationship with risk-taking behavior in India. Revenue growth helps to decrease the volatility of return on assets for India. Meanwhile, it helps to decrease liquidity risk for foreign banks and non-performing loan risk for public banks. For Pakistan, revenue growth helps to decrease capital adequacy risk in case of private banks. In the context of Bangladesh, it increases capital adequacy risk for publicly owned banks. However, revenue growth has not a significant relationship with other forms of risk-taking behaviors. Return on assets shows a significant negative influence on return on equity volatility for Pakistan.

Moreover, it has a significant positive impact on return on equity volatility for Bangladesh and India. Further, it has a significant negative impact on capital adequacy risk for private banks. Return on assets shows diverse outcomes on the risk-taking behavior of banks. In case of Bangladesh, it has a significant positive impact on non-performing loans for private banks, while it shows a significant positive impact on return on assets volatility of foreign banks in case of India also. Firm size shows varying outcomes in all three countries for public, private and foreign banks. It has a significant relationship with the risk of return on equity volatility for Bangladesh. In addition, the cost to income ratio has a significant relationship with all risk-taking behaviors except for return on assets volatility across Pakistan. For India, it has a significant negative impact on capital adequacy ratio only. However, for Bangladesh, the cost to income ratio has mixed outcomes on risk-taking behavior. Furthermore, the insignificant results of Sargan test show that instruments are valid. Outcomes of AR2 reveal insignificant p-values which indicate that we accept the null hypothesis that there is no autocorrelation.

\section{CONCLUSION}

The objective of our study is to find the effect of ownership structure (publicly owned banks, private banks and foreign banks) on risk-taking of banks in Pakistan, India, and Bangladesh. We apply two-step dynamic panel estimation and find that privately and publicly owned banks have a significant impact on bank risk. These banks involve themselves in traditional and non-traditional business activities as well as risk-taking activities. This has become necessary for banks to survive in the globalized business environment. Further, publicly owned banks also have a back door for their survival that is Central bank and the government. The overall analysis also reveals that foreign ownership does not have a significant impact on bank risk-taking behavior. This is due to the fact that foreign banks have not yet developed in South Asian countries. A separate analysis of individual countries shows mixed outcomes of private, public and foreign banks for Pakistan, India, and Bangladesh. Findings reveal that foreign banks are less risky as compared to private and public banks across Pakistan, Bangladesh and India.

In general, private and public banks in Pakistan, India, and Bangladesh have a significant impact on bank risk. However, foreign banks in Bangladesh are also imposing a significant impact on the risk-taking behavior of banks. This shows more trust of foreign investors in banks of Bangladesh whether they are private or public because of more political stability as compared to Pakistan and India. In Pakistan public banks are riskier as compared to foreign and private banks because the return volatility of public bank is higher according to the LCR and NPL which is also inconsistent with the soft budget constraint theory which states that publicly owned banks take political support to handle the issue of nonperforming loans and to increase finance (Li, 1992).

The outcomes provide importance regarding the relationship between risk-taking and ownership structure. It provides a guideline to policymakers to make financial policies according to risk-related activities and ownership structure of banks. In addition, banks can also take benefits as they make economically sound decisions that not only reflect the effect of ownership structure on risk-taking behavior but also construct sound financial policies. The results of this study may be beneficial for investors as well in many ways. The study helps investors in a way that they can invest in those firms having a low risk. On the contrary, our research explains the economy and risk-related activities of banks which motivates foreign investors in developing countries. Banks should also consider risk factors while making business decisions instead of only focusing on diverse sources of income-generating activities. Policies can be generated according to risk-taking patterns of differently owned banks which may be helpful in reducing risks and increasing profitability. Similarly, the results of the study can be implicated or can be used by foreign investors while deciding on properly investing their finances in more profitable areas. Our study is limited to the South Asian region and it does not study the impact on other regions and areas thus making it bound in a single region. In this study, we select private, public, and foreign-owned banks and partial ownership can be added for future studies to find the impact of partial ownership on the risk-taking behavior of banks.

\section{REFERENCES}

1. Aharon, D. Y., \& Yagil, Y. (2019). The impact of financial leverage on the variance of stock returns. International Journal of Financial Studies, 7(1), 14. https://doi.org/10.3390/ijfs7010014

2. Akhtar, Y., Kayani, G. M., \& Yousaf, T. (2019). The effects of regulatory capital requirements and ownership structure on bank lending in emerging Asian markets. Journal of Risk and Financial Management, 12(3), 142. https://doi.org/10.3390/jrfm12030142

3. Allen, J., \& Paligorova, T. (2011). Bank loans for private and public firms in a liquidity crunch (Bank of Canada Working Paper No. 2011-13). https://doi.org/10.2139/ssrn.1844569 
4. Andries, N., \& Billon, S. (2010). The effect of bank ownership and deposit insurance on monetary policy transmission. Journal of Banking \& Finance, 34(12), 3050-3054. https://doi.org/10.1016/j.jbankfin.2010.07.010

5. Arellano, M., \& Bond, S. (1991). Some tests of specification for panel data: Monte Carlo evidence and an application to employment equations. The Review of Economic Studies, 58(2), 277-297. https://doi.org/10.2307/2297968

6. Arellano, M., \& Bover, O. (1995). Another look at the instrumental variable estimation of error-components models. Journal of Econometrics, 68(1), 29-51. https://doi.org/10.1016/0304-4076(94)01642-D

7. Ashfaq, K., Younas, Z. I., \& Mehmood, B. (2014). Impact of ownership structure on default risk: A case of banking sector of Pakistan. Corporate Ownership and Control, 11(2), 144-152. https://doi.org/10.22495/cocv11i2p11

8. Barry, T. A., Lepetit, L., \& Tarazi, A. (2011). Ownership structure and risk in publicly held and privately owned banks. Journal of Banking \& Finance, 35(5), 1327-1340. https://doi.org/10.1016/j.jbankfin.2010.10.004

9. Ben-Nasr, H., Boubaker, S., \& Rouatbi, W. (2015). Ownership structure, control contestability, and corporate debt maturity. Journal of Corporate Finance, 35, 265-285. https://doi.org/10.1016/j.jcorpfin.2015.10.001

10. Boubaker, S., \& Nguyen, D. K. (2014). Corporate governance in emerging markets. https://doi.org/10.1007/9783-642-44955-0

11. Boubaker, S., Nguyen, P., \& Rouatbi, W. (2016). Multiple large shareholders and corporate risk-taking: Evidence from French family firms. European Financial Management, 22(4), 697-745. https://doi.org/10.1111/eufm.12086

12. Boubakri, N., Cosset, J.-C., \& Saffar, W. (2013). The role of state and foreign owners in the corporate risk-taking: Evidence from privatization. Journal of Financial Economics, 108(3), 641-658. https://doi.org/10.1016/j.jfineco.2012.12.007

13. Brandao-Marques, L., Correa, R., \& Sapriza, H. (2012). International evidence on government support and risktaking in the banking sector (European Banking Center Discussion Paper No. 2012-027). https://doi.org/10.2139/ssrn.2169324

14. Chiorazzo, V., Milani, C., \& Salvini, F. (2008). Income diversification and bank performance: Evidence from Italian banks. Journal of Financial Services Research, 33(3), 181-203. https://doi.org/10.1007/s10693-008-00294

15. Choi, S., \& Hasan, I. (2005). Ownership, governance, and bank performance: Korean experience. Financial Markets, Institutions \& Instruments, 14(4), 215-242. https://doi.org/10.1111/j.0963-8008.2005.00104.x

16. Demirgüc-Kunt, A., \& Detragiache, E. (2002). Does deposit insurance increase banking system stability? An empirical investigation. Journal of Monetary Economics, 49(7), 1373-1406. https://doi.org/10.1016/S03043932(02)00171-X

17. Djankov, S., \& Murrell, P. (2002). Enterprise restructuring in transition: A quantitative survey. Journal of Economic Literature, 40(3), 739-792. https://doi.org/10.1257/jel.40.3.739

18. Dong, Y, Meng, C, Firth, M, \& Hou, W. (2014). Ownership structure and risk-taking: Comparative evidence from private and state-controlled banks in China. International Review of Financial Analysis, 36, 120-130. https://doi.org/10.1016/j.irfa.2014.03.009

19. Drakos, A. A, Kouretas, G. P, \& Tsoumas, C. (2016). Ownership, interest rates and bank risk-taking in Central and Eastern European countries. International Review of Financial Analysis, 45, 308-319. https://doi.org/10.1016/j.irfa.2014.08.004

20. Duqi, A., \& Al-Tamimi, H. A. H. (2018). The impact of owner's identity on banks' capital adequacy and liquidity risk. Emerging Markets Finance and Trade, 54(2), 468-488. https://doi.org/10.1080/1540496X.2016.1262255

21. El-Bannany, M. (2018). Financial reporting quality for banks in Egypt and the UAE. Corporate Ownership \& Control, 15(2), 116-131. https://doi.org/10.22495/cocv15i2art10

22. Estrin, S., Hanousek, J., Kocenda, E., \& Svejnar, J. (2009). The effects of privatization and ownership in transition economies. Journal of Economic Literature, 47(3), 699-728. https://doi.org/10.1257/jel.47.3.699

23. Faleye, O., \& Krishnan, K. (2017). Risky lending: Does bank corporate governance matter? Journal of Banking \& Finance, 83, 57-69. https://doi.org/10.1016/j.jbankfin.2017.06.011

24. Fullenkamp, C., \& Rochon, C. (2017). Reconsidering bank capital regulation: A new combination of rules, regulators, and market discipline. Journal of Economic Policy Reform, 20(4), 343-359. https://doi.org/10.1080/17487870.2016.1181550

25. García-Marco, T., \& Robles-Fernández, M. D. (2008). Risk-taking behavior and ownership in the banking industry: The Spanish evidence. Journal of Economics and Business, 60(4), 332-354. https://doi.org/10.1016/j.jeconbus.2007.04.008

26. Ghosh, S., Nachane, D. M., Narain, A, \& Sahoo, S. (2003). Capital requirements and bank behavior: An empirical analysis of Indian public sector banks. Journal of International Development, 15(2), 145-156. https://doi.org/10.1002/jid.947

27. González, V. M. (2013). Leverage and corporate performance: International evidence. International Review of Economics \& Finance, 25, 169-184. https://doi.org/10.1016/j.iref.2012.07.005

28. Hammami, Y., \& Boubaker, A. (2015). Ownership structure and bank risk-taking: Empirical evidence from the Middle East and North Africa. International Business Research, 8(5), 271-284. https://doi.org/10.5539/ibr.v8n5p271

29. Haque, F., \& Shahid, R. (2016). Ownership, risk-taking and performance of banks in emerging economies: Evidence from India. Journal of Financial Economic Policy, 8(3), 282-297. https://doi.org/10.1108/JFEP-09-20150054

30. Hunjra, A. I., Mehmood, R., \& Tayachi, T. (2020). How do corporate social responsibility and corporate governance affect stock price crash risk? Journal of Risk and Financial Management, 13(2), 30. https://doi.org/10.3390/jrfm13020030

31. Hunjra, A. I., Perveen, U., Li, L., Chani, M. I., \& Mehmood, R. (2020). Impact of ownership concentration, institutional ownership and earnings management on stock market liquidity. Corporate Ownership \& Control 17(2), 77-87. https://doi.org/10.22495/cocv17i2art7

32. Iannotta, G, Nocera, G, \& Sironi, A. (2013). The impact of government ownership on bank risk. Journal of Financial Intermediation, 22(2), 152-176. https://doi.org/10.1016/j.jfi.2012.11.002 
33. Iannotta, G., Nocera, G., \& Sironi, A. (2007). Ownership structure, risk and performance in the European banking industry. Journal of Banking \& Finance, 31(7), 2127-2149. https://doi.org/10.1016/j.jbankfin.2006.07.013

34. Jamil, N. A, Said, R. M, \& Nor, F. M. (2015). Ownership structure and risk taking of Malaysian commercial banks: The moderating effects of capital adequacy ratio. Mediterranean Journal of Social Sciences, 6(6 S4), 139-147. http://doi.org/10.5901/mjss.2015.v6n6s4p139

35. Jensen, M. C., \& Meckling, W. H. (1976). Theory of the firm: Managerial behavior, agency costs and ownership structure. Journal of Financial Economics, 3(4), 305-360. https://doi.org/10.1016/0304-405X(76)90026-X

36. La Porta, R., Lopez-de-Silanes, F., \& Shleifer, A. (2002). Government ownership of banks. The Journal of Finance, 57(1), 265-301. https://doi.org/10.1111/1540-6261.00422

37. Lepetit, L., Nys, E., Rous, P., \& Tarazi, A. (2008). The expansion of services in European banking: Implications for loan pricing and interest margins. Journal of Banking \& Finance, 32(11), 2325-2335. https://doi.org/10.1016/j.jbankfin.2007.09.025

38. Li, D. D. (1992). Public ownership as a sufficient condition for the soft budget constraint (University of Michigan, Center for Research on Economic \& Social Theory Working Paper No.93-07). Retrieved from https://deepblue.lib.umich.edu/handle/2027.42/100860

39. Liu, H., Molyneux, P., \& Nguyen, L. H. (2012). Competition and risk in South East Asian commercial banking. Applied Economics, 44(28), 3627-3644. https://doi.org/10.1080/00036846.2011.579066

40. Lotto, J. (2018). The empirical analysis of the impact of bank capital regulations on operating efficiency. International Journal of Financial Studies, 6(2), 34. https://doi.org/10.3390/ijfs6020034

41. Lotto, J., \& Mwemezi, J. (2015). Assessing the determinants of bank liquidity: Experience from Tanzanian banks. African Journal of Finance and Management, 24(1-2), 76-88. Retrieved from https://www.researchgate.net/publication/335174695_Assessing_the_Determinants_of_Bank_Liquidity_Experie nce_from_Tanzanian_Banks

42. Maji, S. G., \& De, U. K. (2015). Regulatory capital and risk of Indian banks: A simultaneous equation approach. Journal of Financial Economic Policy, 7(2), 140-156. https://doi.org/10.1108/JFEP-06-2014-0038

43. Mehmood, R., Hunjra, A. I., \& Chani, M. I. (2019). The impact of corporate diversification and financial structure on firm performance: Evidence from South Asian Countries. Journal of Risk and Financial Management, 12(1), 49. https://doi.org/10.3390/jrfm12010049

44. Miller, G. S., \& Skinner, D. J. (2015). The evolving disclosure landscape: How changes in technology, the media, and capital markets are affecting disclosure. Journal of Accounting Research, 53(2), 221-239. https://doi.org/10.1111/1475-679X.12075

45. Nichols, D. C., Wahlen, J. M., \& Wieland, M. M. (2009). Publicly traded versus privately held: Implications for conditional conservatism in bank accounting. Review of Accounting Studies, 14(1), 88-122. https://doi.org/10.1007/s11142-008-9082-3

46. Nisar, S., Peng, K., Wang, S., \& Ashraf, B. N. (2018). The impact of revenue diversification on bank profitability and stability: Empirical evidence from South Asian countries. International Journal of Financial Studies, 6(2), 40. https://doi.org/10.3390/ijfs6020040

47. Perera, S., Skully, M. \& Wickramanayake, J. (2006). Competition and structure of South Asian banking: A revenue behaviour approach. Applied Financial Economics, 16(11), 789-801. https://doi.org/10.1080/09603100600687461

48. Pinto, G., \& Rastogi, S. (2019). Sectoral analysis of factors influencing dividend policy: Case of an emerging financial market. Journal of Risk and Financial Management, 12(3), 110. https://doi.org/10.3390/jrfm12030110

49. Rime, B. (2001). Capital requirements and bank behaviour: Empirical evidence for Switzerland. Journal of Banking \& Finance, 25(4), 789-805. https://doi.org/10.1016/S0378-4266(00)00105-9

50. Samet, A., Boubakri, N., \& Boubaker, S. (2018). Does public-private status affect bank risk taking? Worldwide evidence. Journal of International Financial Markets, Institutions and Money, 53, 287-306. https://doi.org/10.1016/j.intfin.2017.12.007

51. Srairi, S. (2013). Ownership structure and risk-taking behaviour in conventional and Islamic banks: Evidence for MENA countries. Borsa Istanbul Review, 13(4), 115-127. https://doi.org/10.1016/j.bir.2013.10.010

52. Stiroh, K. J., \& Rumble, A. (2006). The dark side of diversification: The case of US financial holding companies. Journal of Banking and Finance, 30(8), 2131-2161. https://doi.org/10.1016/j.jbankfin.2005.04.030

53. Trinh, T. H., Duyen, T. T. T., \& Thao, N. T. (2015). The impact of corporate governance on financial risk in Vietnamese commercial banks. International Journal of Economics and Finance, 7(7), 123-130. https://doi.org/10.5539/ijef.v7n7p123

54. Weiß, G. N. F., Bostandzic, D., \& Neumann, S. (2014). What factors drive systemic risk during international financial crises? Journal of Banking \& Finance, 41, 78-96. https://doi.org/10.1016/j.jbankfin.2014.01.001

55. Williams, B. (2016). The impact of non-interest income on bank risk in Australia. Journal of Banking and Finance, 73, 16-37. https://doi.org/10.1016/j.jbankfin.2016.07.019

56. Yao, H., Haris, M., \& Tariq, G. (2018). Profitability determinants of financial institutions: Evidence from banks in Pakistan. International Journal of Financial Studies, 6(2), 53. https://doi.org/10.3390/ijfs6020053

57. Zeitun, R., \& Tian, G. G. (2007). Does ownership affect a firm's performance and default risk in Jordan? Corporate Governance, 7(1), 66-82. https://doi.org/10.1108/14720700710727122

58. Zhang, J., Jiang, C., Qu, B., \& Wang, P. (2013). Market concentration, risk-taking, and bank performance: Evidence from emerging economies. International Review of Financial Analysis, 30, 149-157. https://doi.org/10.1016/j.irfa.2013.07.016

59. Zhu, W, \& Yang, J. (2016). State ownership, cross-border acquisition, and risk-taking: Evidence from China's banking industry. Journal of Banking \& Finance, 71, 133-153. https://doi.org/10.1016/j.jbankfin.2016.05.004 